\title{
Integrated stream and wetland restoration: A watershed approach to improved water quality on the landscape
}

\author{
Curtis J. Richardson*, Neal E. Flanagan, Mengchi Ho, James W. Pahl \\ Duke University Wetland Center, Nicholas School of the Environment, Box 90333, Durham, NC 27708, USA
}

\section{A R T I C L E I N F O}

\section{Article history:}

Received 10 May 2010

Received in revised form

20 September 2010

Accepted 22 September 2010

\section{Keywords:}

Urban watershed

Stream restoration

Wetland restoration

Nitrogen

Phosphorus

Sediment

\begin{abstract}
A B S T R A C T
Water quality in Upper Sandy Creek, a headwater stream for the Cape Fear River in the North Carolina Piedmont, is impaired due to high $\mathrm{N}$ and $\mathrm{P}$ concentrations, sediment load, and coliform bacteria. The creek and floodplain ecosystem had become dysfunctional due to the effects of altered storm water delivery following urban watershed development where the impervious surface reached nearly $30 \%$ in some sub-watersheds. At Duke University, an 8-ha Stream and Wetland Assessment Management Park (SWAMP) was created in the lower portion of the watershed to assess the cumulative effect of restoring multiple portions of stream and former adjacent wetlands, with specific goals of quantifying water quality improvements. To accomplish these goals, a three-phase stream/riparian floodplain restoration (600 $\mathrm{m})$, storm water reservoir/wetland complex ( $1.6 \mathrm{ha})$ along with a surface flow treatment wetland $(0.5 \mathrm{ha})$ was ecologically designed to increase the stream wetland connection, and restore groundwater wetland hydrology. The multi-phased restoration of Sandy Creek and adjacent wetlands resulted in functioning riparian hydrology, which reduced downstream water pulses, nutrients, coliform bacteria, sediment, and stream erosion. Storm water event nutrient budgets indicated a substantial attenuation of $\mathrm{N}$ and $\mathrm{P}$ within the SWAMP project. Most notably, $\left(\mathrm{NO}_{2}{ }^{-}+\mathrm{NO}_{3}{ }^{-}\right)-\mathrm{N}$ loads were reduced by $64 \%$ and $\mathrm{P}$ loads were reduced by $28 \%$. Sediment retention in the stormwater reservoir and riparian wetlands showed accretion rates of $1.8 \mathrm{~cm}$ year $^{-1}$ and $1.1 \mathrm{~cm}$ year $^{-1}$, respectively. Sediment retention totaled nearly $500 \mathrm{MT}_{\mathrm{Tear}}{ }^{-1}$.
\end{abstract}

(c) 2010 Elsevier B.V. All rights reserved.

\section{Introduction}

A nationwide assessment of streams in the U.S. found that $42 \%$ of stream lengths was in poor condition, with the most widespread stressors identified as nitrogen $(\mathrm{N})$, phosphorus $(\mathrm{P})$, streambed sediments, and riparian disturbance (Paulsen et al., 2006). More than $30 \%$ of the rivers in the United States are listed as impaired by USEPA (2002) and restoration of these waters has resulted in a nationwide explosion of stream and riparian wetland projects. Since 1990 it is estimated that $>1$ billion dollars have been spent each year on restoration, mostly on piecemeal selection of restoration sites to meet regional or local mitigation requirements with less than $10 \%$ of the projects reporting any assessment data, and unfortunately with little or no monitoring as to the effectiveness of current restoration practices (Bernhardt et al., 2005).

Shields et al. (2010) point out that watershed development triggers stream channel incision that often leads to dramatic changes in channel morphology, which in turns greatly alters water quality, discharge concentrations, and aquatic habitats and

\footnotetext{
* Corresponding author. Tel.: +1 11919613 8006; fax: +1 119196138101 .

E-mail address: curtr@duke.edu (C.J. Richardson).
}

fish populations. In addition, it has recently been reported that the gravel/sediment bedded streams thought characteristically to meander in the past on a self formed floodplain in the midAtlantic may not be the ideal restoration goal since analysis of historic soils and floodplains show that many streams before European settlement were small anabranching (braided streams on the floodplain) channels within extensive vegetated wetlands that accumulated little sediment but stored substantial organic carbon (Walter and Merritts, 2008). Walter and Merritt's study suggests that that current geomorphic stream based restoration approaches (Rosgen, 1994) sweeping the nation as a stream re-establishment method will not result in the return of historic stream/wetland communities nor the ecological services they once provided on the landscape. It also suggests that the use of ecological design principles as suggested by Zedler (2000) and Doll et al. (2003) and amplified by Lake et al. (2007) must be incorporated into modern stream/wetland restoration in order to restore more ecological functions and services. For example, it has been shown that wetland function is closely related to landscape position and that specific hydrologic regimes must be restored to enhance biodiversity or wetland function (Zedler, 2000).

Bedford (1999) concluded that cumulative alteration of landscapes is the greatest constraint on wetland restoration. Her finding 


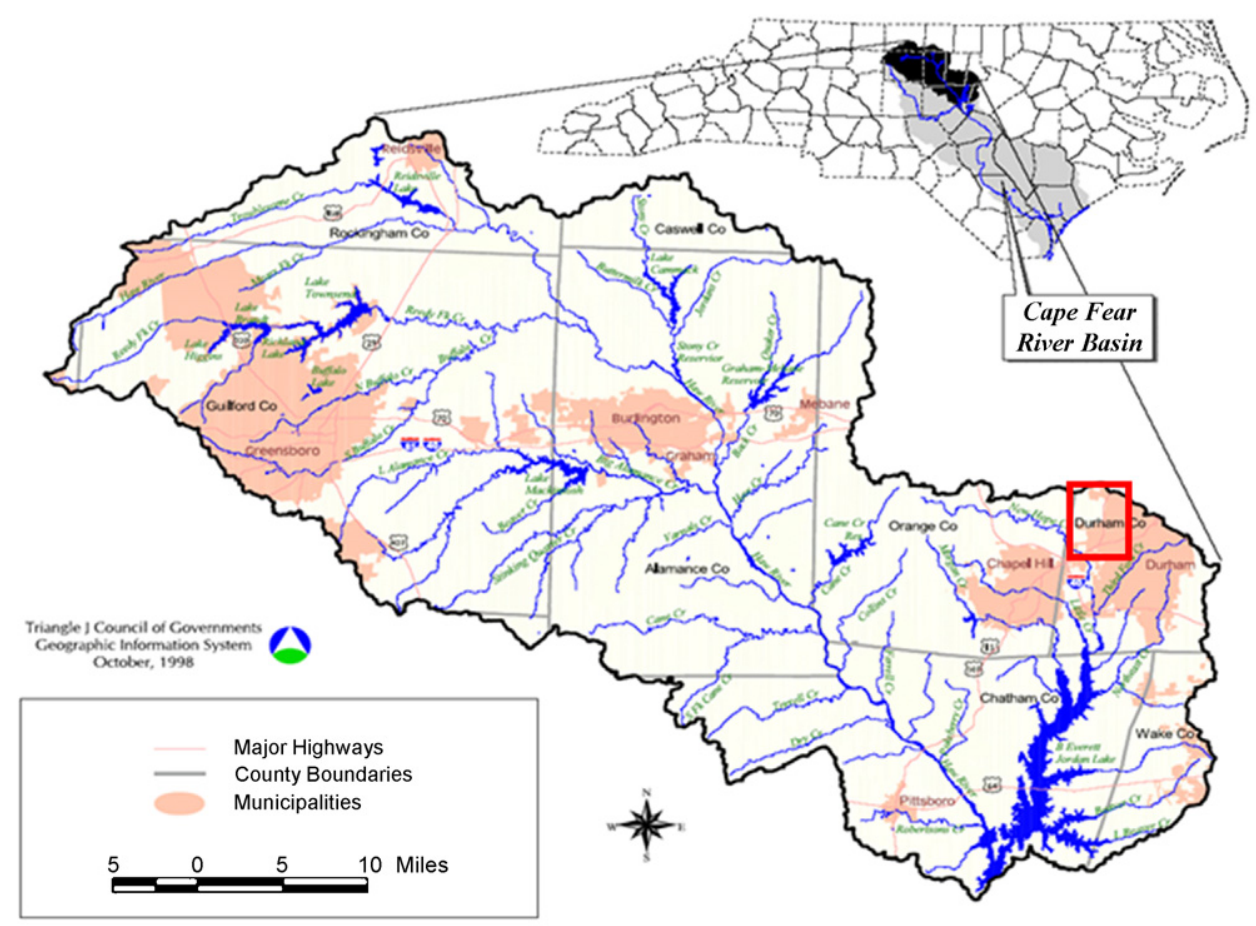

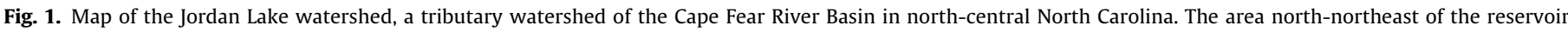
highlighted by the red box is the Sandy Creek watershed feeding into upper New Hope Creek.

suggests that piecemeal restoration projects that do not take a total watershed approach are limited in their effectiveness to improve water quality and biodiversity on the landscape. Bernhardt and Palmer (2007) also propose that to be effective, urban stream restoration efforts must be integrated within broader catchment management strategies. They also note that a key scientific and management challenge is to establish criteria for determining when the design options for urban river restoration are so constrained that a return towards reference or pre-urbanization conditions is not realistic or feasible and when river restoration presents a viable and effective strategy for improving the ecological condition of these degraded ecosystems.

These studies and reviews collectively suggest the need for a testing and quantification of the effects of cumulative additions of both stream and wetland restoration projects within a watershed, especially in the urban landscape. It is well known that wetlands and riparian zones provide flood control, nutrient retention or removal, erosion control, water quality maintenance, carbon storage, open space and wildlife habitat (Richardson, 1994; Zedler, 2003; Mitsch and Gosselink, 2007). However, research has indicated that wetlands vary in ecological characteristics and functions. Richardson (1994) and Zedler (2000) have pointed out that different wetlands provide difference services in the watershed and that not all wetlands provide all services. Therefore, successfully restoring a diversity of wetlands, which are functionally equivalent to their natural counterparts, requires a more complex approach than simply adding water. While substantial efforts are being made to revitalize the natural ecosystem functions of streams and degraded riparian ecosystems (Mitsch et al., 2000, 2002), many are unsuccessful due to a lack of understanding of the complexities of these systems and their interactions on the landscape (Zedler, 2000; Bernhardt and Palmer, 2007). The purpose of this study was to assess the cumulative effect of restoring increased portions of stream and former adjacent wetlands in a urban/forested watershed with the specific goals to quantify water quality improvements, and an increase in wetland hydrologic functions. Our objectives were to (1) quantify the cumulative effects of stream/wetland restoration phases in a watershed on the downstream water quality and (2) assess if the adjacent wetland hydrology and function have been successfully restored.

\section{Background}

\subsection{Regional site description}

The pre-European Piedmont of North Carolina was a mosaic of prairie, savannah and forest communities (Lawson, 1714; Schafale and Weakley, 1990; Luczkovich and Knowles, 2001), partially situated on the Piedmont's Triassic Basin. The bedrock of this basin is highly impermeable and exhibits extremely low base flows to central North Carolina watersheds. Upon weathering the Triassic Basin bedrock forms clays below the soil horizons that are additionally impermeable to water (Buol, 2003). As a result, watersheds in the region, such as the Sandy Creek and New Hope Creek watersheds in the Cape Fear River Basin (Fig. 1) demonstrate naturally high surface runoff to sub-surface flow ratios. With minimal potential groundwater infiltration, non-point surface runoff into floodplains and stream courses is therefore the dominant fate of precipitation in this part of central North Carolina.

Land-use practices since European settlement of the region and intensive agriculture in central North Carolina during the late nineteenth and early twentieth century have increased non-point source discharge patterns and resulted in excessive erosion of as much as $17 \mathrm{~cm}$ of upland topsoil (Forest History Society, 2000) into floodplain streambeds and wetlands (Trimble, 1974). As agriculture declined in the late twentieth century, the sediments deposited in the stream channels began to erode. Incision of the stream into the bed sediments and increased shear stress on bank sediments resulted in deepened and straightened drainages with increased 

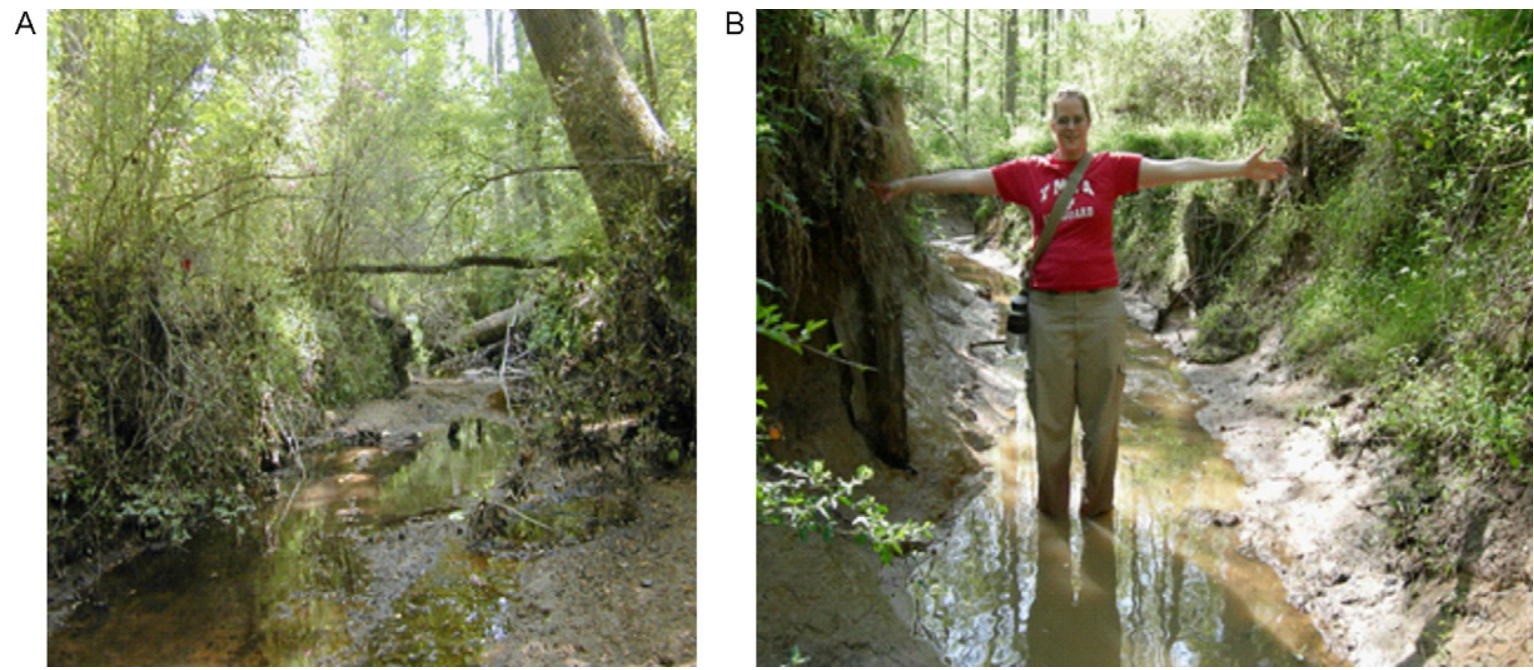

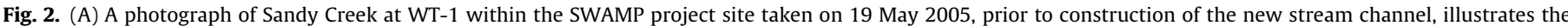

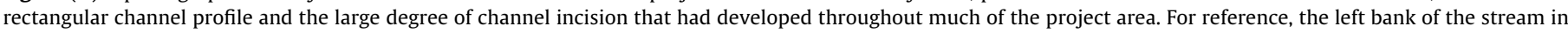

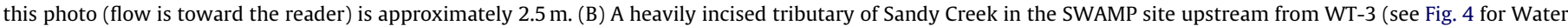
Transect (WT) locations site locations).

flow velocities. Undercutting of bank vegetation and bank collapse also resulted, and the streams themselves have become a source of suspended sediments (Fig. 2A and B). While this process of channelization "is an efficient method for moving water quickly out of an area, this is a poor configuration for maintaining habitat integrity, leading to sandy or silt bottomed channels unsuitable for most aquatic organisms", (Rosgen, 1994; Doll et al., 2003; Elting, 2003).

Thus, modern conversion of agricultural and forested lands to residential and commercial purposes in the Piedmont exacerbated floodplain erosion. As a watershed is urbanized, the extent of "impervious surface" increases, with concrete and blacktop associated with roads and parking lots as well as building rooftops (Elting, 2003; Bernhardt and Palmer, 2007). Not only do impervious surfaces result in a decrease in the area of land surface available for infiltration of storm water, but also dedicated engineered structures are put in place to intentionally remove as rapidly as possible storm water that falls onto those surfaces. This is in direct opposition to natural hydrologic processes characterized by a gradual delivery of storm water to adjacent receiving streams following infiltration through upland and floodplain soils. Pulse flows aggravate the erosion occurring within the streambed, with impacts related to the extent of impervious cover in the watershed. The rapid delivery of storm water to the adjacent receiving streams and floodplains leads to degradation of both physical and ecological structure within those systems, and the extent of damage increases rapidly and predictably as the extent of impervious surface within a watershed increases (Bernhardt and Palmer, 2007).

\subsection{Study area}

The Sandy Creek floodplain has been impacted by deposition of eroded upland sediments and cut off from stream bank overflow due to deeply incised steam channels (Fig. 2A and B). These changes have created altered hydrologic patterns representative of a highly developed urban watershed, which is no longer capable of improving water quality for stream-borne nutrients, sediments and contaminants. As a result, Sandy Creek delivers impaired waters into New Hope Creek and the downstream Jordan Lake drinking reservoir. The watershed of the eastern branch of Upper Sandy Creek drains over 600 ha of southwestern Durham County, mostly in the City of Durham and 341 ha of the west campus of Duke University (Fig. 3A). Within the Sandy Creek watershed, approximately $30 \%$ of the soils in the watershed is classified as either urban soils or urban soil complexes, which are essentially impervious following compaction and removal of topsoil (Elting, 2003). Sandy Creek receives nonpoint surface runoff from a variety of landscape features such as a botanical garden, a cemetery, a golf course, parking lots and suburban residential areas, and the Duke Campus, as well as from undeveloped forest. The watershed has a mean impervious area of $20.6 \%$, with individual sub-watersheds ranging from 12.6 to $29.0 \%$, much of which has drainage directly funneled into Sandy Creek watershed stream courses (Fig. 3B). Consistent with the predictable degradation of the stream and floodplain the Sandy Creek streambed widened and became severely incised $(>2 \mathrm{~m}$ in many places) into the floodplain, with a rectangular cross-channel profile (Fig. 2A and B). These changes in stream morphology, coupled with the spread of impervious surfaces in the watershed has allowed for the rapid transport of nutrient- and contaminant-laden surface water into and through the floodplain stream system (Flanagan et al., 2008).

The specific study area for this stream/wetland research is the Duke University Stream and Wetland Assessment Management Park (SWAMP), located in Durham, NC $\left(35^{\circ} 59^{\prime} 27.78^{\prime \prime} \mathrm{N}\right.$, $\left.78^{\circ} 56^{\prime} 31.09^{\prime \prime} \mathrm{W}\right)$. Measuring approximately 8.5 ha in size, the wetland study site includes the main channel of Sandy Creek, adjacent tributaries and riparian areas of the floodplain labeled as restoration Phases 1-3 (Fig. 3B). Phase 4 is under construction. According to soil maps (Kirby, 1976), the most widespread soil series present at the site is the Cartecay (coarse-loamy, mixed semiactive, nonacid, thermic Aquic Udifluvent)/Chewacla (fine-loamy, mixed, active, thermic Fluvaquentic Endoaquepts) soil series. These sandy loamy soils are formed on floodplains through alluvial sedimentation and are considered to be hydric soils (USDA/NRCS, 2009). Soil series on adjacent uplands include Mayodan, White Store, and Pinkstone series. These soils are mostly restricted to the upland areas, which are outside the influence of sedimentation from flooding, and are all non-hydric. The post-restoration floodplain of Sandy Creek regularly receives floodwater during moderate to high rainfall events; however, the volume and frequency of overbank flooding can vary at different locations along the stream channel 

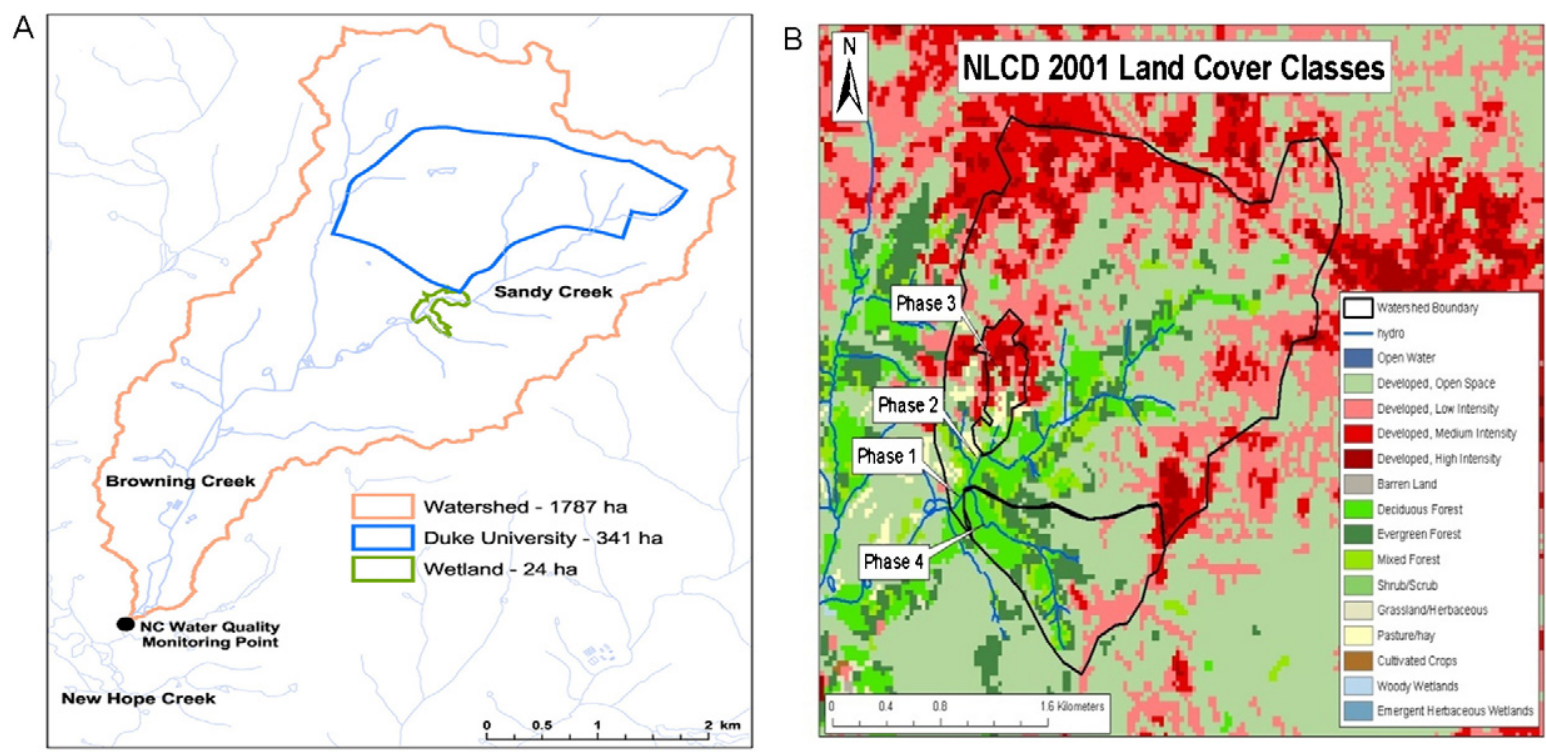

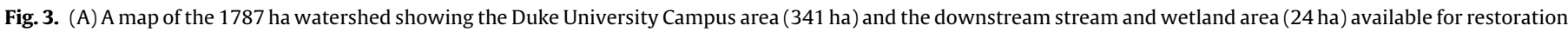

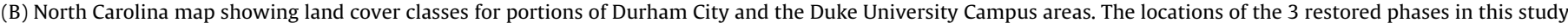
are shown along with Phase IV, which is currently under restoration.

(Flanagan et al., 2008). A recent spatial study of the soils of the study site revealed that soil organic matter significantly decreased after restoration, while exchangeable $\mathrm{P}$ increased and nitrate-nitrogen did not differ (Unghire et al., 2010).

The forests in the Sandy Creek watershed are primarily second-growth following abandonment of agriculture in the early twentieth century (Elting, 2003). Watts (2000) identified portions of the floodplain community as qualifying as wetland vegetation. However, most of the hydrophytic vegetation (wetland indicator status listed by USFWS as Facultative wet, FACW or Facultative, FAC) seen was in the canopy tree layer, which was dominated by sweet gum (Liquidambar styraciflua: FAC+), with sycamore (Platanus occidentalis: FACW-), red maple (Acer rubrum: FAC), tulip poplar (Liriodendron tulipifera: FAC) and American elm (Ulmus americana: FACW) as subdominants. Watts (2000) found evidence that the site was transitioning to a more terrestrial character, particularly with the shrub and herbaceous communities. The shrub/sapling stratum was overwhelmingly dominated by an invasive Chinese privet (Ligustrum sinense: FAC), with pignut (Carya glabra: FACU) and mockernut hickory (Carya alba: FACU) identified as subdominants, and the herbaceous layer was dominated by an exotic invasive Japanese stilt grass (Microstegium vimineum: FAC+). Watts (2000) attributed this transition to the lack of overbank flooding into the floodplain from the greatly incised stream channel during storm events (Fig. 2A and B). Due to the downward excision of the streambed through the aforementioned alluvial deposits now present in the riparian areas, the Sandy Creek floodplain had become hydrologically isolated from the stream (Elting, 2003).

\section{Methods}

\subsection{Stream and wetland restoration approach}

In response to the recognition that the Upper Sandy Creek stream and floodplain ecosystem had become dysfunctional due to the effects of altered storm water delivery following watershed development, a three-phase stream and floodplain restoration was planned by staff and students from the Duke University Wetland Center (DUWC), Duke Forest the Department of Civil and Environmental Engineering and Baker Engineering (Fig. 4A and B). The three phases of restoration planned for the site were:

I. Re-contour and replant more than $600 \mathrm{~m}$ of degraded stream to hydrologically reconnect the stream with the adjacent floodplain and allow natural riparian wetland biogeochemical transformations to improve stream water quality.

II. Build an earthen dam and outflow weir system in conjunction with a 1.6 ha storm water/wetland reservoir to regulate delivery to downstream water bodies and allow for additional retention and removal of excess nutrients and sediments from the stream.

III. Build a 0.5-ha surface flow treatment wetland (SFW) to intercept and improve the water quality of a tributary impacted by high concentrations of $\mathrm{N}$ and $\mathrm{P}$ from the University Campus.

The Phase I stream restoration was done following a natural channel design (Doll et al., 2003) utilizing a reference reach approach integrated with riparian floodplain re-contouring after classifying the original entrenched stream (Fig. 2B) as a G5 following Rosgen (2007). The reference reach was a first order stream classified as a C-5 following Rosgen (1994) and used as a template for restoration design. The design utilized a priority 1 approach (Fig. 5) where the old channel was filled and a new stable channel created following reference reach geomorphology and regional urban design curves (Doll et al., 2002). The design parameters were based on a determination of the proper bed, bank and flood plain cross-geometry. The determination of the dominant channel forming discharge, often referred to as the bankfull bench effective discharge or channel forming flow was calculated to occur between 1.1 and 1.8 years of discharge for the Piedmont of NC (Doll et al., 2003). Key to this design was the integration of floodplain benches. New first and second bottom elevations were contoured into the landscape to ensure stream-wetland hydrologic connections. In Phase II, a 1.6 ha storm water/wetland pond was constructed with a 5-m outflow dam controlled by a hydraulic weir that could raise or lower the water $1 \mathrm{~m}$ in the storm water pond to alter water 

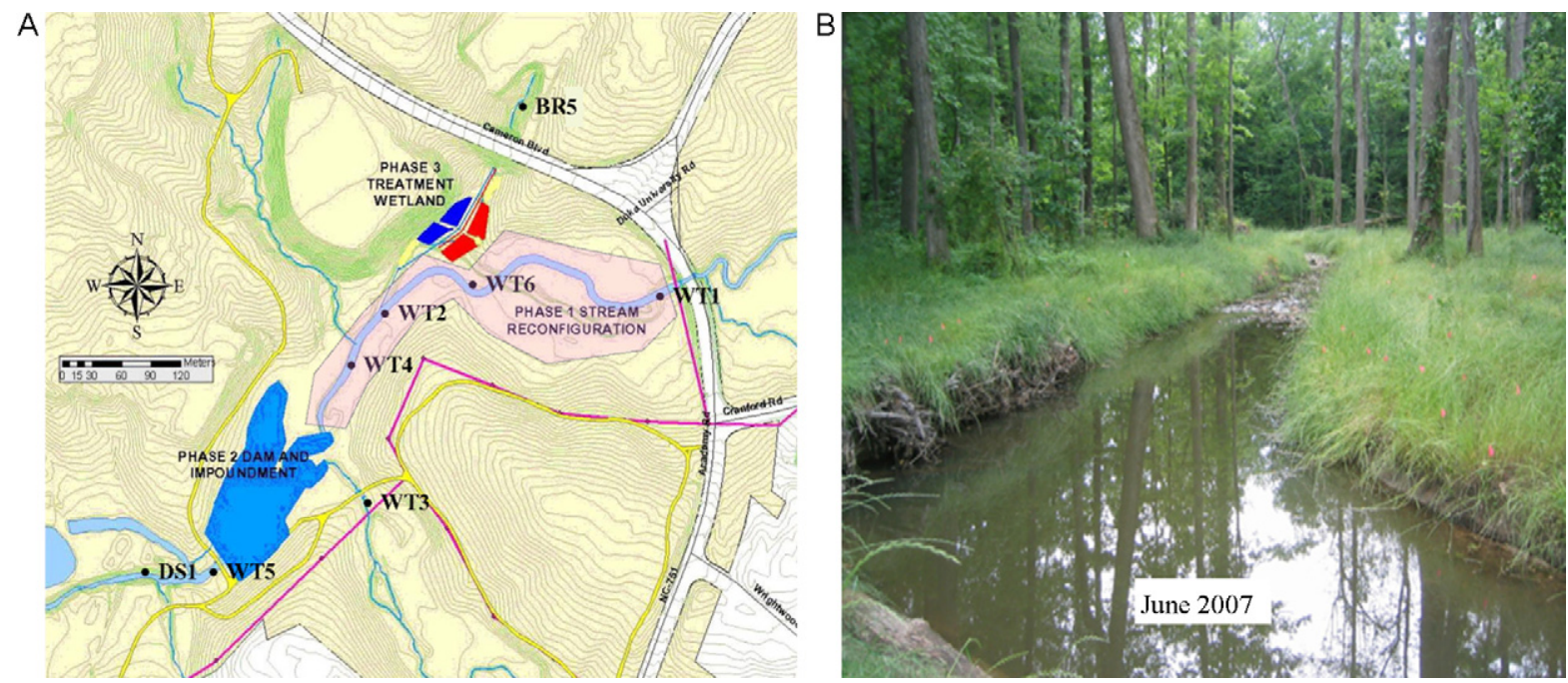

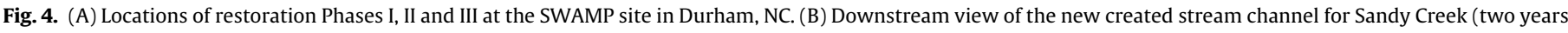

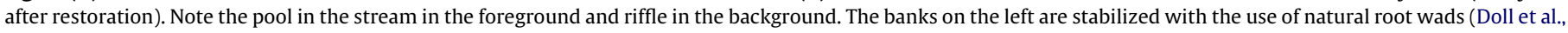
2003).

contact with the sediments and control invasive species. The pond was created with multiple water depth areas (1-8 $\mathrm{m})$ and a shallow $<0.5 \mathrm{~m}$ depth area near the outflow from Sandy Creek for lacustrine wetland plant community development. Phase III consisted of a series of 6 ( 0.5 ha in total size) surface flow wetland cells designed to treat runoff waters from 25 ha of Duke University campus runoff. Three connected wetland cells were placed on each side of the stream with earthen berms designed to retain storm water events. Low flows remained in the mainstream channel downstream of the outflow pipe. Storm events were distributed to the wetland cells via a compound weir system designed to keep low flows in the channel with a $90^{\circ} \mathrm{v}$-notch and storm events shunted to the wetland cells by a broad crested concrete weir. Downstream outflows were measured in a Parshall flume with an automatic pressure transducer water level recorder and standard equations.

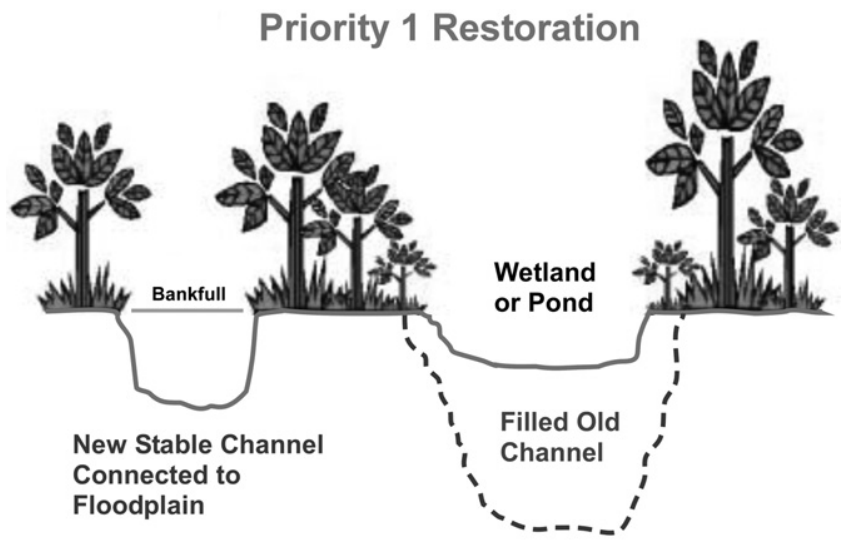

Fig. 5. A cross-sectional profile of a priority 1 stream/wetland restoration (from Doll et al., 2003). Severely incised streams with bank height ratios greater than 1.8 are usually classified as Rosgen stream types G or F. Shear stress at high flows in these streams may become very high, increasing the potential for stream bank erosion and/or streambed down cutting. In a priority 1 restoration the old channel is filled and a new stable channel is established to connect the stream with the floodplain. Note: BKF refers to bankfull, which in the new channel is at the historic floodplain level. The new stream would be classified as an E or C following Rosgen (2007).

\subsection{Water quality sampling and analysis}

\subsubsection{Water quality under base-flow conditions and storm events}

Eight monitoring stations were established in the Upper Sandy Creek watershed and on New Hope Creek between July 2003 and March 2004 to establish a baseline of pre-construction water quality within Sandy Creek (Fig. 4A). Station locations were structured to sample the main stem of Sandy Creek as it moves through the Duke Forest SWAMP site, accounting for contributions of tributary stream inputs at BR-5 and WT-3 (Fig. 4B). These stations corresponded to those established by Turley (2001) for a pre-restoration determination of upper watershed stream water quality, and additionally utilized by Elting (2003) to model nutrient loading in the watershed. Two additional stations were established upstream and downstream of the confluence of Sandy Creek and New Hope Creek to determine the long-term effects of our collective restoration project on water quality (stations not shown). Two of the midstream Sandy Creek stations, WT-2 and WT-6, had to be relocated to the new stream channel sections (note: portions of the old stream channel were kept and only slightly enhanced since they were not highly incised) following the completion of the Phase I stream channel construction to capture the main stem flow of the creek in the new channel in August 2004. In June 2005 we added an eleventh station (MC-1) in Mud Creek, the next tributary of New Hope Creek upstream (NHCU) of the Sandy Creek confluence as a reference station (station not shown). The catchment for this station is largely forested, and there has been no restoration effort on Mud Creek.

Ambient (base-flow) water quality was determined through a combination of grab and in situ sampling both prior to and after (July 2000-August 2004) the Duke Forest Project Phase I stream restoration. Phase II dam construction and completion of a storm water/wetland pond was done by December 2005 and a treatment wetland was completed in the spring of 2007. Ambient base flow sampling was defined as there having been no rain event resulting in a discernible increase in stream stage height for a 3-day period prior to sampling. In 2007 we installed weirs and automatic water level recording equipment at the inflows and outflows to develop daily base-flows and storm delivery and export estimates for nutrients and sediment from the entire study area.

On each sampling date the parameters listed in Table 1 were determined using either a YSI 556 Multi Probe System (YSI Envi- 
Table 1

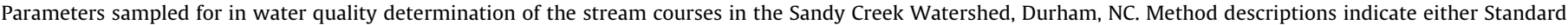
Methods (SM) or USEPA standard protocols.

\begin{tabular}{|c|c|c|c|}
\hline In situ measurement & Biweekly grab samples & Units & Analytical method \\
\hline Temperature & & ${ }^{\circ} \mathrm{C}$ & SM2550B \\
\hline Specific conductivity & - & $\mathrm{mS} \mathrm{cm}^{-1}$ & SM2510B \\
\hline Conductivity & - & $\mathrm{mS} \mathrm{cm}^{-1}$ & SM2510B \\
\hline Total dissolved solids (TDS) & - & $\mathrm{g} / \mathrm{L}$ & Calculated \\
\hline Salinity & - & PPt & Calculated \\
\hline Dissolved $\mathrm{O}_{2}(\mathrm{DO})$ & - & $\mathrm{mg} / \mathrm{L}$ and $\%$ saturation & SM 4500-O G \\
\hline $\mathrm{pH}$ & - & $\mathrm{pH}$ & SM 4500-H A \\
\hline- & Fecal coliforms (FC) & Colonies/100 mL & SM9222D \\
\hline- & Biochemical oxygen demand (BOD) & $\mathrm{mg} / \mathrm{L}$ (5 day) & SM5210B \\
\hline- & Alkalinity & $\mathrm{mg} / \mathrm{L}$ & EPA 310.1 \\
\hline- & $\mathrm{NH}_{4}^{+}-\mathrm{N}$ & $\mu \mathrm{g} / \mathrm{L}$ & EPA 350.1 \\
\hline- & $\left(\mathrm{NO}_{3}^{-}+\mathrm{NO}_{2}^{-}\right)-\mathrm{N}$ & $\mu \mathrm{g} / \mathrm{L}$ & EPA 353.2 \\
\hline- & Total N & $\mu g / L$ & EPA 353.2 \\
\hline- & Soluble reactive P & $\mu \mathrm{g} / \mathrm{L}$ & SM 4500-P E \\
\hline- & Total P & $\mu \mathrm{g} / \mathrm{L}$ & SM 4500-P E \\
\hline- & Calcium & $\mu \mathrm{g} / \mathrm{L}$ & SM3111B \\
\hline- & Magnesium & $\mu g / L$ & SM3111B \\
\hline- & Sodium & $\mu g / L$ & SM3111B \\
\hline- & Potassium & $\mu g / L$ & SM3111B \\
\hline- & Total solids & $\mathrm{g} / \mathrm{L}$ & SM2540B \\
\hline- & Turbidity (TUR) & NTU & SM2130B \\
\hline
\end{tabular}

ronmental, Yellow Springs, OH, USA) for in situ measurements or an HDPE dipper for grab samples for laboratory analysis. The YSI probe was placed in the thalweg of the stream at the relevant station and values were allowed to equilibrate for $1 \mathrm{~min}$ before reading. Grab samples for BOD and solids + turbidity were placed into plasticcoated borosilicate Wheaton bottles and $500-\mathrm{mL}$ polycarbonate bottles on site, respectively. Samples for fecal coliforms and alkalinity were placed into 50-mL polypropylene sterile tubes, samples for total $\mathrm{N}$ and total $\mathrm{P}$ were placed into $50-\mathrm{mL}$ tubes acidified with $9 \mathrm{~N}$ $\mathrm{H}_{2} \mathrm{SO}_{4}$, samples for SRP were filtered through a 0.45 - $\mu$ m nylon filter (Nylon Acrodisc GF Syringe Filter, Pall Life Sciences, Ann Arbor, MI, USA) into 50-mL tubes, samples for $\mathrm{NH}_{4}{ }^{+}-\mathrm{N}$ and $\left(\mathrm{NO}_{3}{ }^{-}+\mathrm{NO}_{2}{ }^{-}\right)-\mathrm{N}$ were filtered through a $0.45-\mu \mathrm{m}$ nylon filter into 50 -mL tubes acidified with $9 \mathrm{~N} \mathrm{H}_{2} \mathrm{SO}_{4}$, and samples for $\mathrm{Ca}, \mathrm{Mg}$, $\mathrm{Na}$ and $\mathrm{K}$ were filtered through a $0.45-\mu \mathrm{m}$ nylon filter into $50-\mathrm{mL}$ tubes acidified with $8 \mathrm{~N}$ $\mathrm{HNO}_{3}$. Samples were analyzed in the lab following the methods listed in Table 1.

\subsubsection{Groundwater response to stream and floodplain restoration}

Twenty wells were originally installed in the SWAMP site in the Durham Division at Duke Forest in 2000 to monitor groundwater levels prior to restoration. The locations of the wells coincide to vegetation survey transects previously established in 1999 (Watts, 2000). Sixteen wells were located on the bank and nearby floodplain of Sandy Creek. Four wells, located in a tributary of Sandy Creeks, served as reference wells because this area would not be impacted by restoration related construction activities. Water table readings were manually recorded every two weeks using an electronic resistance meter. Starting in October 2000, readings were taken every other week. Automated RDS water wells were installed at low and high bench floodplain locations in 2006 to follow storm effects on groundwater and establish if wetland hydrology has been reestablished. Just over four years of water table data are available for determination of restoration affects on riparian water table depth before and after re-establishment of the floodplain. Sediment in the storm water pond and riparian wetlands was measured using the feldspar marker technique (Cahoon and Turner, 1989). Twenty marker horizons were placed in both the floodplain and storm water pond in 2006, and sediment buildup was measured over a four-year period.

\subsubsection{Data handling and statistical analysis}

Prior to analysis, water quality data were aggregated into four sampling periods, pre-restoration, Phase I stream restoration, Phase II dam and storm water retention pond construction, and Phase III treatment wetlands. Analysis of these phases separately allowed for the determination of the effects of multiphase stream and floodplain/wetland restoration on surface water quality in the watershed. Data were initially subjected to a QA/QC analysis based on the USEPA “ $5 \times$ rule" (Section 5.5 of USEPA, 1989). Briefly, sample values from a particular sampling trip that were less than $5 \times$ the highest parameter value found in any field blanks from that date were assigned a "non-detect" status. If blanks were not available for a particular date, then $5 \times$ the value of the lowest standard used to calibrate the parameter analysis was utilized as the detect/nondetect threshold. Non-detect data were handled as per EPA(2000a). Since all parameters had $<15 \%$ non-detects, a value of $1 / 2$ the DUWC Analytical Lab minimum detection limit (MDL) was used in place of the non-detect data. It should be noted that we also calculated an MDL for each parameter by calculating the mean $( \pm 95 \% \mathrm{CI})$ of all the blanks for a specific parameter for each sampling period (Prior, Phase I, Phase II, Phase III).

Data were checked for normality and homogeneity of variance prior to analysis, and parameters not meeting these criteria were subject to data transformation (e.g., $\log _{10} x$, arcsine) in order to help meet the assumptions of the ANOVA. A correlation analysis between all response variables for the ambient water quality assessment was performed, and on the basis of the results the data were aggregated into a single data set for analysis via a multivariate analysis of variance (MANOVA). Fecal coliforms, total N, pH, and turbidity were omitted from the MANOVA because of missing parameter values from several sampling dates; MANOVA will exclude all information from a line of data values if a single parameter is missing, and we felt that the resulting loss of data was not justified. Although these parameters were excluded from the MANOVA, the $\alpha$-level for multiple comparisons testing in subsequent parameter-specific post hoc ANOVAs were corrected to reflect the total number of response variables examined in this study.

Data were classified by station and sampling period as outlined earlier; as a result, the structure of the MANOVA was nested treatment arrangement sampling site $(n=11)$ and period (site). Because 


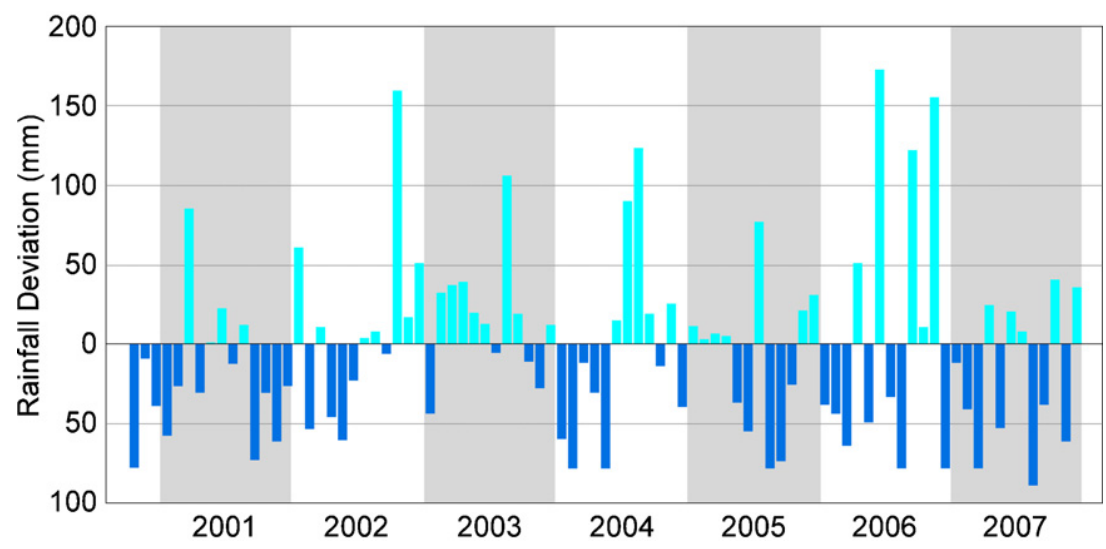

Fig. 6. Monthly rainfall deviation from a six-decade average in Raleigh-Durham Airport, $15 \mathrm{~km}$ from the SWAMP site in NC.

of the lack of data from station MC-1 during the pre-restoration (PRIOR period) this site was not included in post hoc multiple comparisons of the pre and post restorations phases. The MANOVA and ANOVAs were performed using PROG GLM in SAS for Windows V.9.1 (SAS Institute, Cary, NC, USA). The MANOVA indicated that both site and period (site) were overall significant effects, and both factors were thus used in the post hoc ANOVAs in order to run a Tukey-adjusted multiple comparisons of treatment-level mean values. A Pearson's correlation comparison was run between variables to determine overall relationships. To evaluate water quality improvement through the SWAMP site, mean daily upstream-todownstream changes in water quality constituents were compared between sampling periods using the non-parametric Wilcoxon Sign test for paired sites using a correction of $p$-values to control for false discovery rate. The model evaluated the effect of sampling period on changes in constituent concentration (deltas) through the SWAMP site (downstream concentrations minus upstream concentration, WT5-WT1, for a given sampling date). A positive delta indicates an increase, and a negative delta shows a decrease in constituent concentration as Sandy Creek flow through the SWAMP project area. Dunnett's procedure for multiple comparisons with a control was used to adjust $p$-values. In these comparisons the control was defined as deltas observed during the pre-restoration period. These analyses where performed for selected constituents of concern mentioned in the Jordan Lake TMDL (NCDENR/DWQ 2007).

\section{Results and discussion}

\subsection{Restoration of hydrologic wetland zones}

By definition, jurisdictional wetlands include areas that are saturated within $30 \mathrm{~cm}$ of the surface for $5 \%$ of the growing season in 4 or more years out of 10 (USACE, 1987). The criteria that are set to recognize hydric conditions thus require lengthy observations. We used these criteria to establish if our stream restoration and resulting bank overflow would result in a reconnection of the floodplain with the pulsed water regime of the creek. This was essential since a pre-restoration groundwater survey indicated that only 0.3 ha of the entire 24 ha SWAMP site met the hydrologic conditions for wetlands (unpublished data).

Since the onset of the groundwater and stream measurements in Duke Forest, the North Carolina Piedmont area has experienced frequent drought and high rainfall conditions. Both 2001 and 2007 years had an annual deficit more than $170 \mathrm{~mm}$ (Fig. 6). In contrast, Durham received an annual rainfall surplus of $280 \mathrm{~mm}$ in 2006, an exceptional drought condition in 2007 immediately followed. Thus, the SWAMP groundwater monitoring efforts have experienced the hydrologic dynamics of wetland habitats under both drought and wet conditions.

During "Phase I" stream reconfiguration hydrologic wetland zones on the riparian floodplains separated by $15 \mathrm{~cm}$ in elevation were created in the floodplain on the banks of Sandy Creek (Fig. 7A-D). The water tables were often elevated to within $30 \mathrm{~cm}$ of the soil surface or during 2006 were above the soil surface for large portions of the year. Although, readings were missing from high bench area data loggers during portions of 2006 and 2007, May levels were similar in both years and indicative of wetland hydrology at all sites. These data coupled with four years of manual water level recording and piezometer wells in the bench areas (data not shown) all indicated that the wetland hydrology criteria were being met at all elevations in both the low and high bench floodplain areas (Flanagan et al., 2008). Field observations also indicated that the low bench areas closest to the stream were often flooded, especially after storms. Thus, both high and low bench floodplains met wetland criteria during both 2006 and 2007, suggesting a strong connections between the restored stream and the floodplain. The reestablishment of the stream/wetland hydrologic connections was essential to our plan for improving water quality downstream by allowing stream water to flow over the adjacent floodplains during overbank flow.

\subsection{Water quality under ambient (base-flow) conditions}

Retention and cycling of nutrients on riverine floodplains are strongly affected by the interplay of hydrology with geomorphology (Brinson, 1977; Johnston et al., 2001; Mitsch and Gosselink, 2007). The efficiency of riparian wetlands in regulating such ecosystem services as nitrogen removal is not only a function of surface area, but also of the hydrologic length of contact between the riparian zone and stream sources of nutrient loading from the larger watershed (Haycock and Pinay, 1993). Any changes in water regimes that alter the frequency and duration of flooding directly affect nitrogen cycling in alluvial soils by altering the duration of oxic and anoxic conditions and by controlling nutrient loads to wetlands (Pinay et al., 2002). Phosphorus retention in wetlands is tied mainly to soil sorption processes and sedimentation (Richardson, 1999). It was thus imperative that wetland $N$ and $P$ biogeochemical processes and hydrologic stream flow conditions be restored to the Sandy Creek floodplain riparian system to enable them to provide their nutrient removal services on the watershed.

There was a significant effect of sampling station location on all parameters except temperature (Table 2). Project sampling period before and after restoration phases also had a significant effect on 

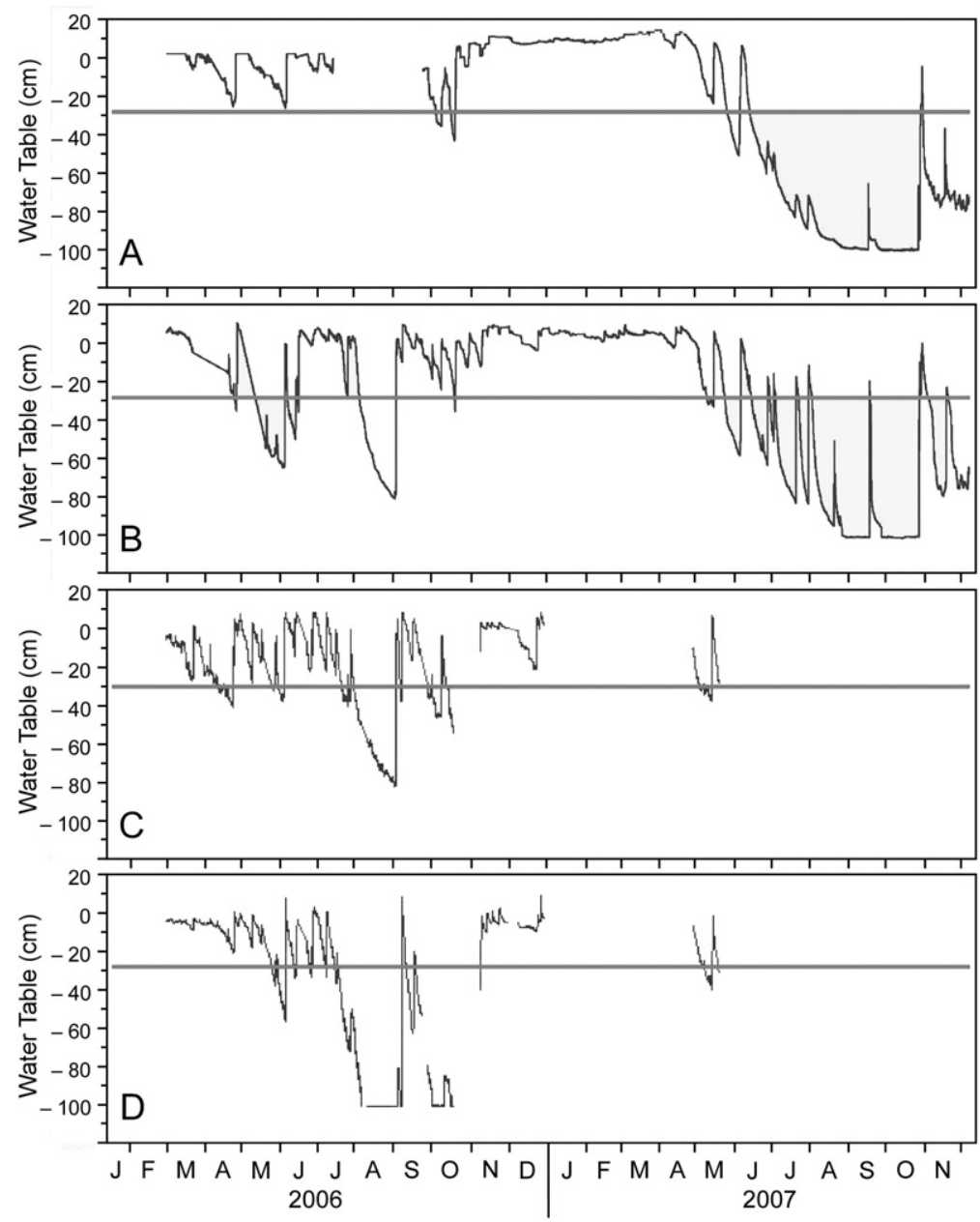

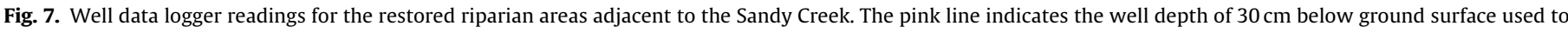

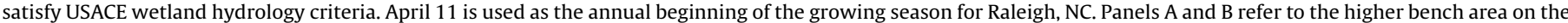

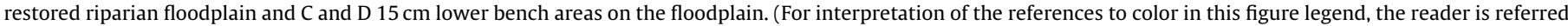
to the web version of this article.)

all response parameters except total phosphorus (TP) and soluble reactive phosphorus (SRP). In periods "Prior", "Phase I" and "Phase II" we saw a general trend of decreasing temperature and $\mathrm{pH}$ values at stations throughout the study area. This trend was reversed in Phase III (data not shown) as drought conditions and low flow conditions effect between period means. Temperature and $\mathrm{pH}$ were strongly correlated throughout this study $(p \leq 0.0001)$; and we documented lower $\mathrm{pH}$ values in winter both at this site and the Mud Creek reference stream. Differences between sampling stations themselves, averaged across time, were a significant source of variation for $\mathrm{pH}$, but not for temperature. Temperatures varied over the years and averaged $17.2 \pm 2,14.4 \pm 2.5,10.5 \pm 1.6$, and $17.4 \pm 2.3^{\circ} \mathrm{C}$ for the Prior, Phase I, Phase II and Phase III sampling periods, respectively at the inflow (WT-1) location. All instantaneous temperature observations and calculated means were within established NCDENR/DWQ standard of values below $32^{\circ} \mathrm{C}$ for lower Piedmont, non-trout streams (NCDENR/DWQ 2004). pH values mostly met the NC water quality standard $\mathrm{pH}$ of 6-9 except for Mud Creek (MC-1) and WT-3 after Phase III was in place (Fig. 8A).

Dissolved $\mathrm{O}_{2}$ was highly variable across the phases of restoration (Fig. 8B), but there was an obvious trend of decreasing percent saturation at all but one station (BR-5) and this trend was statistically significant at most stations during the Phase III period (Appendix A) due to high temperatures and low flows during extreme drought conditions during the Summer of 2007, this also included stations at the upstream boundaries of the SWAMP project area (WT-1, WT-3, BR-5). Over the entire sampling period MC-1 had the lowest time-averaged dissolved $\mathrm{O}_{2}$ content ( $54.7 \pm 7.4 \%$ ), with stations DS-1, WT-3, and WT-5 also below a mean of 65\% saturation $(61.6 \pm 5.9,62.0 \pm 7.5,64.2 \pm 4.7$, respectively), while station WT- 6 in the middle of the Phase II restoration had the highest time-averaged $\mathrm{dO}_{2}$ content of $88.4 \pm 5.2 \%$ saturation. These spatial patterns largely reflect structural differences in the streams at those particular stations: For example, MC- 1 on Mud Creek is a deeply incised, slow flowing stream near a bridge replacement. WT-5 is within the retention basin of the pre-existing concrete dam, and DS- 1 is just downstream of the concrete dam. By comparison, station WT-6 is a riffle section over cobbles built to increase aeration in the newly restored stream.

Specific conductivity varied significantly across space, where values were lowest in New Hope (NHCU) and Mud Creek (MC-1), intermediate in the Sandy Creek main stem stations and at WT-3, and highest at BR-5; which suggests that this tributary is a significant source of dissolved chemical species to Sandy Creek (Fig. 9A) Similar patterns were seen for salinity and total dissolved solids (data not shown). While time-averaged mean values for these three parameters increased in no cases were those increases statistically different, and all mean values for TDS were below the NC water 
Table 2

Results of post hoc ANOVAs on water quality data. Model and treatment component significant $p$-values $<0.05$ are highlighted in bold type.

\begin{tabular}{|c|c|c|c|c|}
\hline \multirow[t]{2}{*}{ Parameter } & \multicolumn{2}{|l|}{ Model } & \multicolumn{2}{|c|}{ Model component } \\
\hline & $F$ & $p>F$ & $\begin{array}{l}\text { Site }(d f=10) \\
p>F\end{array}$ & $\begin{array}{l}\text { Period }(d f=3) \\
p>F\end{array}$ \\
\hline \multicolumn{5}{|c|}{ Component parameters of MANOVA } \\
\hline Temperature ${ }^{a}$ & 2.05 & 0.0003 & 0.2581 & 0.0001 \\
\hline Dissolved $\mathrm{O}_{2}$ & 3.67 & $<0.0001$ & 0.0026 & $<0.0001$ \\
\hline Specific conductivity & 8.17 & $<0.0001$ & $<0.0001$ & $<0.0001$ \\
\hline Salinity & 8.35 & $<0.0001$ & $<0.0001$ & 0.0001 \\
\hline Total dissolved solids & 8.55 & $<0.0001$ & $<0.0001$ & 0.0001 \\
\hline Total solids & 28.14 & $<0.0001$ & $<0.0001$ & 0.0076 \\
\hline $\mathrm{Ca}$ & 21.45 & $<0.0001$ & $<0.0001$ & 0.0001 \\
\hline Alkalinity ${ }^{\mathrm{a}}$ & 10.03 & $<0.0001$ & $<0.0001$ & 0.0006 \\
\hline $\mathrm{Mg}$ & 11.20 & $<0.0001$ & $<0.0001$ & 0.0001 \\
\hline $\mathrm{K}$ & 7.56 & $<0.0001$ & $<0.0001$ & $<0.0001$ \\
\hline $\mathrm{Na}$ & 3.95 & $<0.0001$ & $<0.0001$ & 0.0005 \\
\hline$\left(\mathrm{NO}_{3}^{-}+\mathrm{NO}_{2}^{-}\right)-\mathrm{N}^{\mathrm{a}}$ & 12.85 & $<0.0001$ & $<0.0001$ & $<0.0001$ \\
\hline $\mathrm{NH}_{4}^{+}-\mathrm{N}^{\mathrm{a}}$ & 2.47 & $<0.0001$ & $<0.0001$ & $<0.0001$ \\
\hline Total Pa & 10.92 & $<0.0001$ & $<0.0001$ & 0.3933 \\
\hline Soluble reactive $\mathrm{P}^{\mathrm{a}}$ & 9.66 & $<0.0001$ & $<0.0001$ & 0.3100 \\
\hline \multicolumn{5}{|c|}{ Parameters run independently, separate from MANOVA } \\
\hline $\mathrm{pH}$ & 2.41 & $<0.0001$ & $<0.0001$ & $<0.0001$ \\
\hline Turbidity ${ }^{\mathrm{a}}$ & 4.60 & $<0.0001$ & $<0.0001$ & $<0.0001$ \\
\hline Total Na & 10.44 & $<0.0001$ & $<0.0001$ & $<0.0001$ \\
\hline Fecal coliforms ${ }^{\mathrm{a}}$ & 8.59 & $<0.0001$ & $<0.0001$ & $<0.0001$ \\
\hline $\mathrm{WQI}^{\mathrm{b}}$ & 1.32 & 0.0948 & 0.0001 & 0.4013 \\
\hline
\end{tabular}

Site and period statistical summaries in Appendix A.

a Data were $\log 10_{x}$-transformed to help meet the assumptions of the ANOVA.

b Water quality index (WQI) data were $\operatorname{arcsine}(\sqrt{ } x)$-transformed for the same purpose.

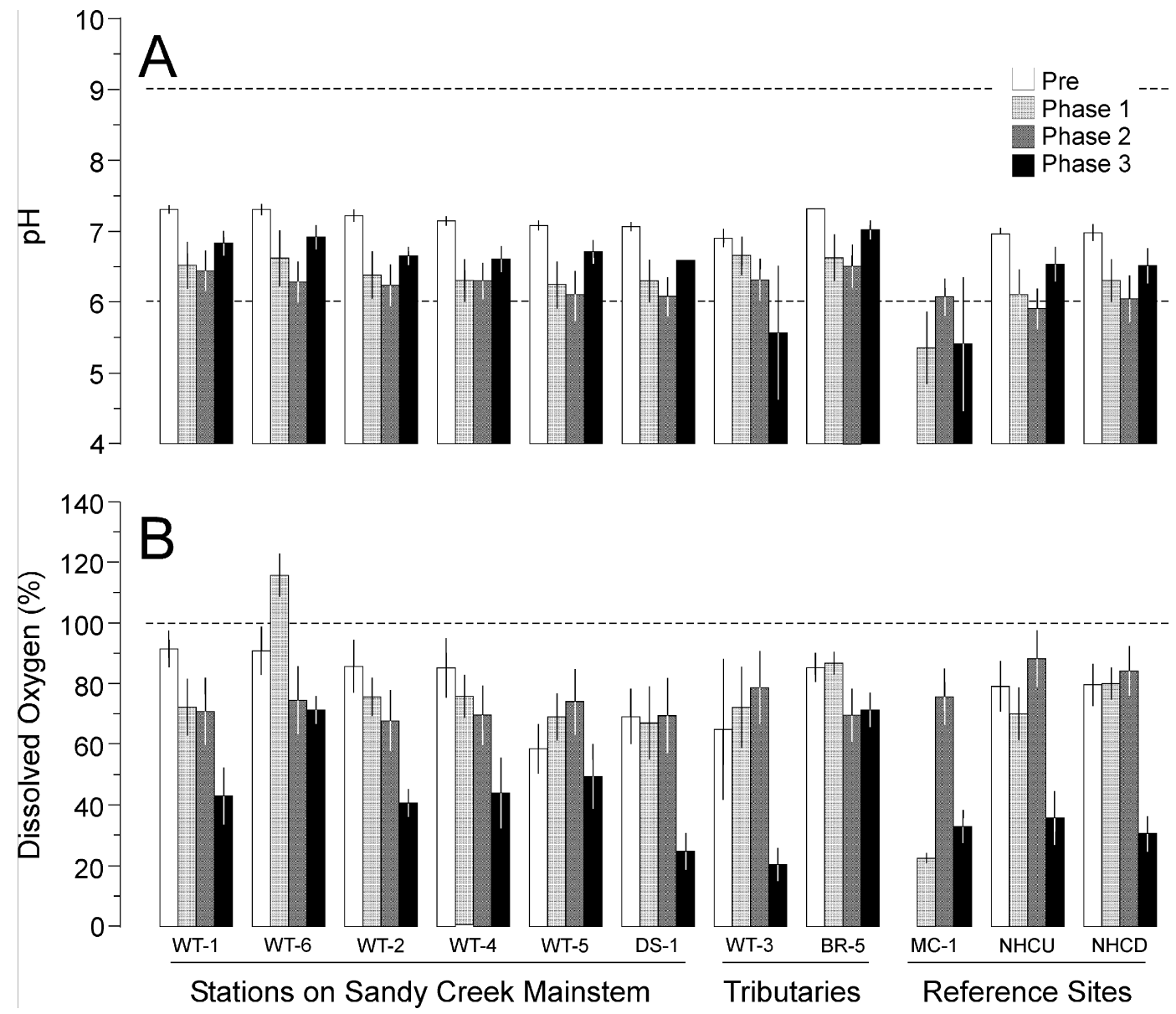

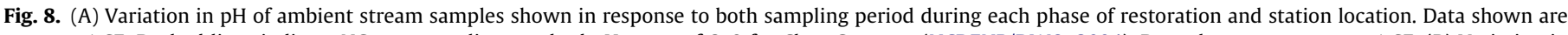

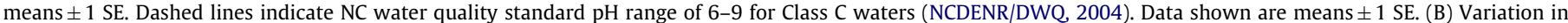

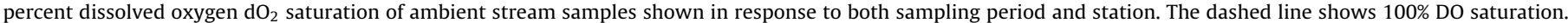
Data shown are means \pm 1 SE. See Fig. 4 for locations of sampling stations and Appendix A for significant differences between period $\times$ site treatments. 


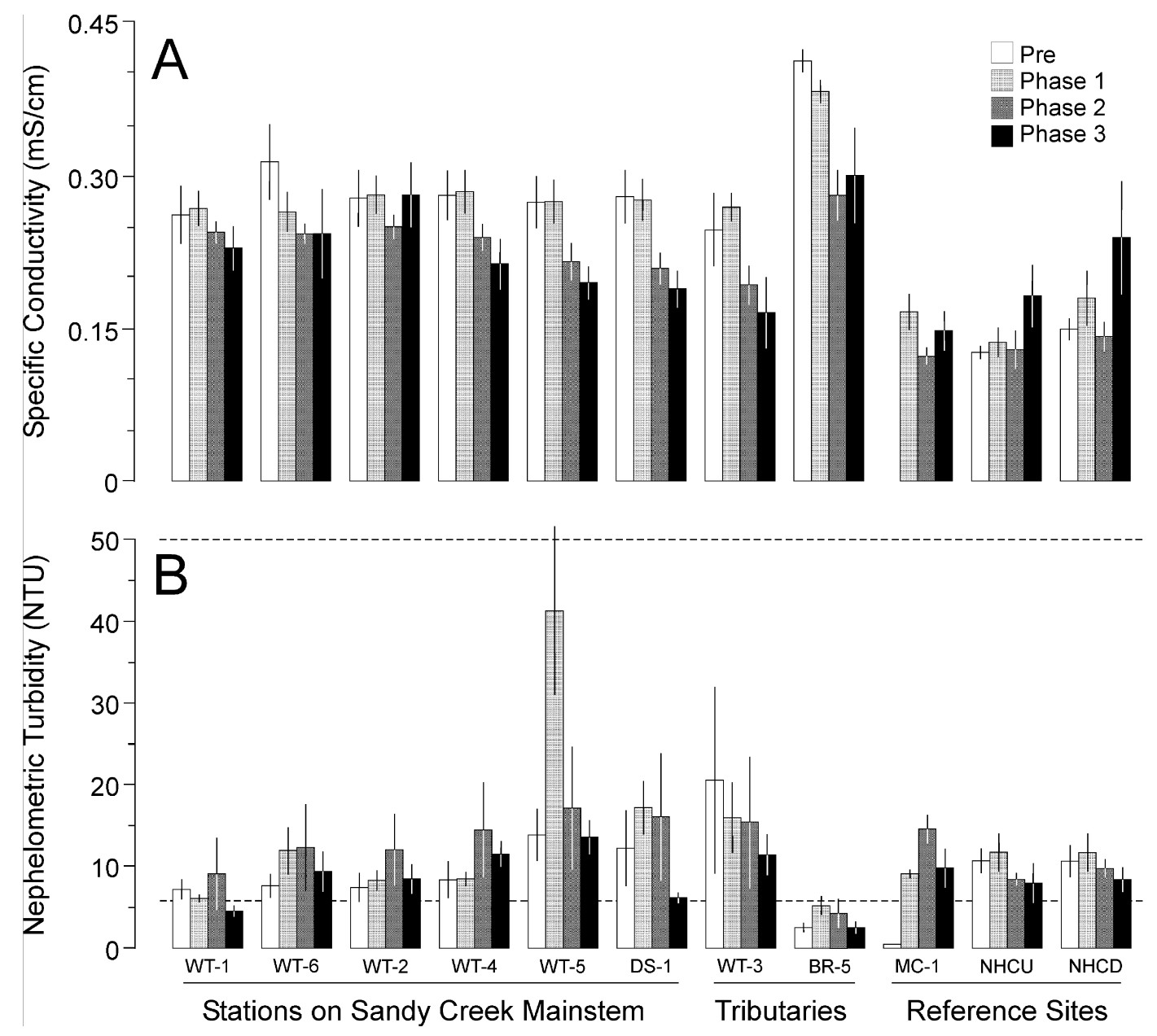

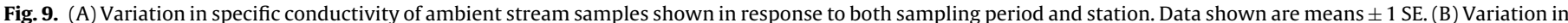

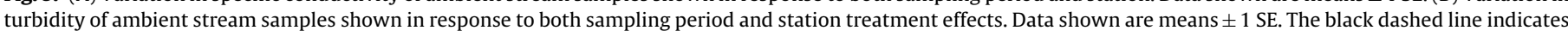

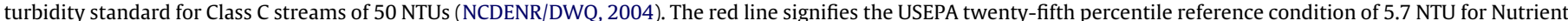

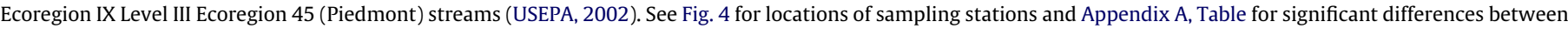
period $\times$ site treatments. (For interpretation of the references to color in this figure legend, the reader is referred to the web version of this article.)

quality standard of $500 \mathrm{mg} / \mathrm{L}$ for WS-IV waters (NCDENR/DWQ, 2004). Supporting the assertion that dissolved salts and other chemicals were the primary component of the solids load in these streams, specific conductivity, salinity, total dissolved solids, and total solids were all significantly and positively correlated ( $p$-values for correlation $<0.0001$ ).

In contrast to these response patterns, overall date-averaged turbidity was lowest at BR-5 compared to the remaining stations, both within and outside of the Sandy Creek restoration area. During Phase I, turbidity at station WT-5 was significantly elevated in comparison to either prior to restoration or after the completion of Phase II (Fig. 9B), which was likely an artifact of this station's position downstream of the dam construction site. There were no significant differences in turbidity between sampling periods for the other stations (Appendix A). Mean values were less than the NC water quality standard of 50 NTUs (NCDENR/DWQ, 2004), but generally greater than the EPA's reference criteria for Piedmont stream systems of 5.7 NTU (USEPA, 2000b). Total suspended solids (TSS) for this project site and for a similar urban Piedmont restoration project we had in Charlotte, NC were negligible during low ambient flow sampling events and were consistently less than the measurement error. However, we did measure significant TSS during storm events, with significant amounts being trapped during bank overflow. Importantly, feldspar markers put at the soil surface in 2006 to measure sediment retention in the stormwater reservoir and riparian wetlands showed accretion rates of $1.8 \mathrm{~cm}_{\text {year }}{ }^{-1}$ and $1.1 \mathrm{~cm}$ year $^{-1}$, respectively. When bulk density of sediment and areal extent was combined with accretion rate, this translated into 89 metric tonnes per year of sediment being retained in the stormwater reservoir and 399 metric tonnes in the floodplain.

For all stations within the Upper Sandy Creek floodplain except BR-5, time-averaged fecal coliform counts exceeded the NC standard of 200 colonies $/ 100 \mathrm{~mL}$ sample in Phase I, although there was significant temporal variation in the data (Fig. 10). Phase III fecal coliform counts were significantly lower at all stations on the main stem of Sandy Creek as compared to the "Prior" phase (Appendix A). Coliform counts in both Mud and New Hope Creeks were below the State of NC standard period-specific means. The absence of elevated coliforms at BR-5 was largely a function of the nature of the runoff collected by that tributary, which begins as an actual perennial stream perhaps $50 \mathrm{~m}$ upstream from our sampling station at the outfall from a series of pipes. These pipes channel the accumulated storm water runoff for much of Duke University West Campus, and are near the outfalls. Much of this water is chlorinated (e.g., air conditioner chiller water). We measured an average $\mathrm{Cl}$ concentration of $240 \pm 2 \mu \mathrm{g} / \mathrm{L}$ from six replicate samples taken at BR-5 on 10 February 2004, significantly higher than the State of NC water quality standard of $17 \mu \mathrm{g} / \mathrm{L}$ for Class C waters (NCDENR/DWQ 2004). 


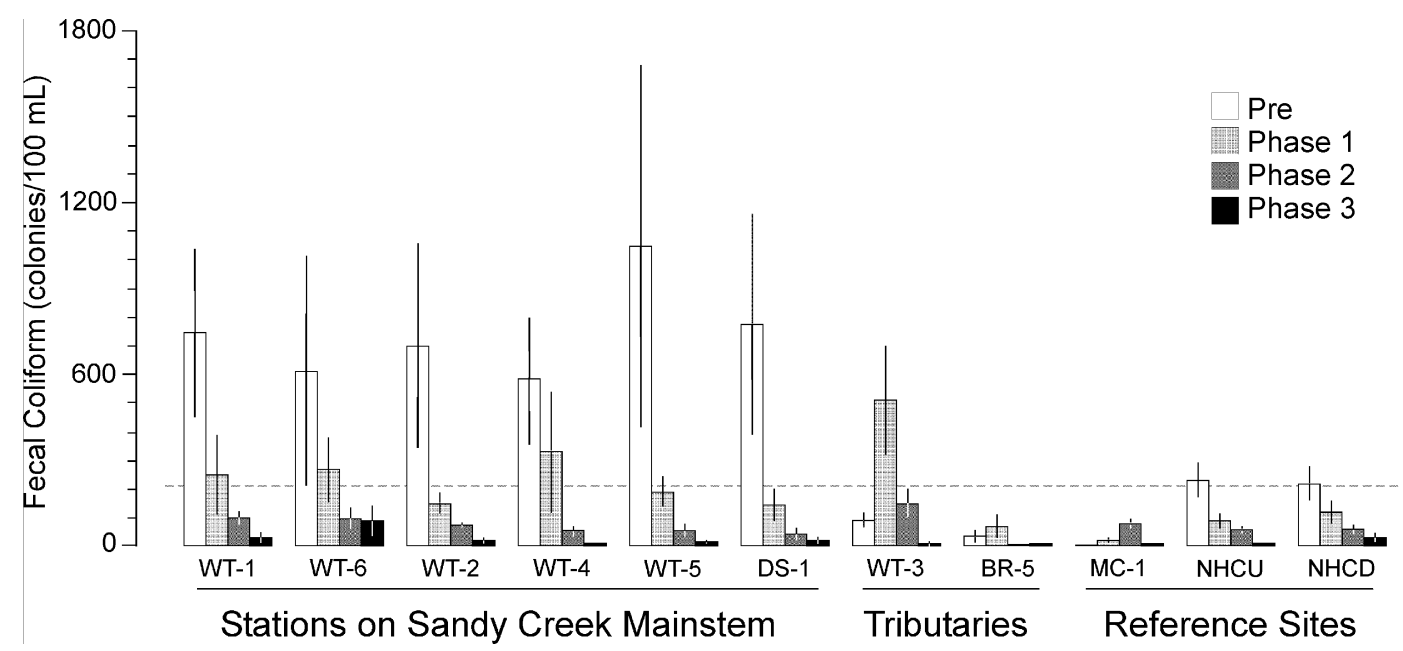

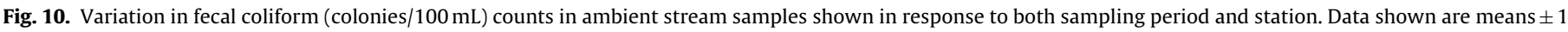

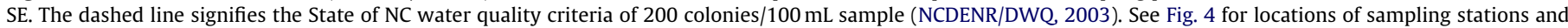
Appendix A, Table for significant differences between period $\times$ site treatments.

The chlorinated nature of this tributary precludes significant fecal coliform growth. Phase III reductions in fecal coliform may also be due to less frequent surface "wash off" events associated with the deepening drought, and the limited survival time of fecal coliform bacteria in upland conditions. Because of the generalized decrease in fecal coliforms over time at all stations, it is difficult to assign these results to the restoration project alone. However, the only stations with statistically significant decreases in fecal coliform concentrations for more than one sampling period are those downstream of the Phase II pond/wetland reservoir (WT-5, DS-1), or those where active chlorination is taking place (BR-5). Thus, the Phase II reservoir may be enhancing a region wide trend of decreased fecal coliform concentrations as particulates carried by Sandy Creek settle out within the reservoir. Thus fecal coliforms leaving the SWAMP site are greatly reduced at the outflow point after Phase II and Phase III.

When averaged across sampling periods, the inorganic fractions of both $\mathrm{N}$ and $\mathrm{P}$ were either a minority or at most a slight majority component of total nutrient load, suggesting that particulate and organic fractions were a substantial component of overall nutrient speciation within our project area (Table 3 ). The exception to this was in the upper reaches of Sandy Creek (BR-5 and WT-6), where the $\left(\mathrm{NO}_{3}{ }^{-}+\mathrm{NO}_{2}{ }^{-}\right)-\mathrm{N}$ fraction accounted for $91 \%$ and $85 \%$ respectively of the total $\mathrm{N}$ fraction. This is consistent with that tributary's $\mathrm{N}$ load being dominated by fertilizer inputs associated with main- tenance of the athletic fields and grounds of Duke University. This also appears to be the case with P in BR-5, where time-averaged SRP was $73 \%$ of total P. The rapid drop in the proportion of inorganic fractions in downstream stations of Sandy Creek (WT-4 and 5) suggests that nutrients are subject to rapid biological uptake and/or transformation through the project area. TP and SRP concentrations (Table 3 ) calculated for most sampling periods within most stations were in excess of the $30 \mu \mathrm{g} / \mathrm{L}$ total P EPA reference condition for Nutrient Ecoregion IX Level III Ecoregion 45 (Piedmont) streams (USEPA, 2002).

\subsection{Paired sites analysis of nitrogen and phosphorus at the SWAMP site}

To examine the overall effects of restoration efforts on $\mathrm{N}$ and $\mathrm{P}$ water quality within the SWAMP project we implemented a BeforeAfter Control Impact (BACI) design (Green, 1979; Stewart-Oaten et al., 1986) where we compared changes in these nutrients as they traveled through the SWAMP site before restoration (Prior or Pre) and during three phases of restoration (Phases I, II, and III). Our control site was defined as water quality monitoring site WT-1 located on the upstream boundary of the SWAMP site where restoration activities have little or no affect on Sandy Creek water quality. Our "impact" site was located on the downstream boundary of the SWAMP project site (WT-5) where Sandy Creek water quality has

Table 3

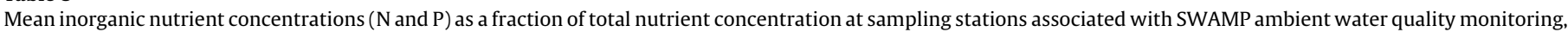
averaged across sampling periods.

\begin{tabular}{|c|c|c|c|c|c|c|c|c|c|}
\hline \multirow[t]{2}{*}{ Sampling station } & \multicolumn{3}{|c|}{ Concentration $N(\mu \mathrm{g} / \mathrm{L})$} & \multicolumn{3}{|c|}{ Fraction of total N (\%) } & \multicolumn{2}{|c|}{ Concentration $(\mu \mathrm{g} / \mathrm{L})$} & \multirow{2}{*}{$\begin{array}{l}\text { Fraction of total P (\%) } \\
\text { SRP }\end{array}$} \\
\hline & Total N & $\mathrm{NO}_{3}{ }^{-}+\mathrm{NO}_{2}^{-}$ & $\mathrm{NH}_{4}^{+}$ & $\mathrm{NO}_{3}{ }^{-}+\mathrm{NO}_{2}^{-}$ & $\mathrm{NH}_{4}^{+}$ & Sum & Total P & SRP & \\
\hline WT1 & 834.8 & 227.5 & 78.3 & 27.2 & 9.4 & 36.6 & 169.0 & 98.2 & 58.1 \\
\hline WT2 & 993.2 & 455.1 & 78.7 & 45.8 & 7.9 & 53.7 & 168.1 & 114.4 & 68.0 \\
\hline WT6 & 845.6 & 654.6 & 66.4 & 77.4 & 7.9 & 85.3 & 144.0 & 80.6 & 55.9 \\
\hline WT4 & 949.7 & 322.9 & 101.7 & 34.0 & 10.7 & 44.7 & 131.8 & 58.9 & 44.7 \\
\hline WT5 & 933.8 & 265.5 & 108.0 & 28.4 & 11.6 & 40.0 & 144.3 & 49.2 & 34.1 \\
\hline DS1 & 945.8 & 245.7 & 224.7 & 26.0 & 23.7 & 49.7 & 135.9 & 78.5 & 57.7 \\
\hline BR5 & 3120.9 & 2696.4 & 159.0 & 86.4 & 5.1 & 91.5 & 401.0 & 294.8 & 73.5 \\
\hline WT3 & 682.1 & 59.6 & 56.1 & 8.7 & 8.3 & 17.0 & 54.0 & 19.8 & 36.7 \\
\hline MC1 & 809.9 & 32.5 & 68.8 & 4.0 & 8.5 & 12.5 & 29.2 & 10.7 & 36.6 \\
\hline NHCD & 753.2 & 139.9 & 53.6 & 18.6 & 7.1 & 25.7 & 61.2 & 29.2 & 47.7 \\
\hline $\mathrm{NHCU}$ & 746.0 & 109.2 & 69.2 & 14.6 & 9.3 & 23.9 & 44.7 & 16.1 & 36.0 \\
\hline
\end{tabular}




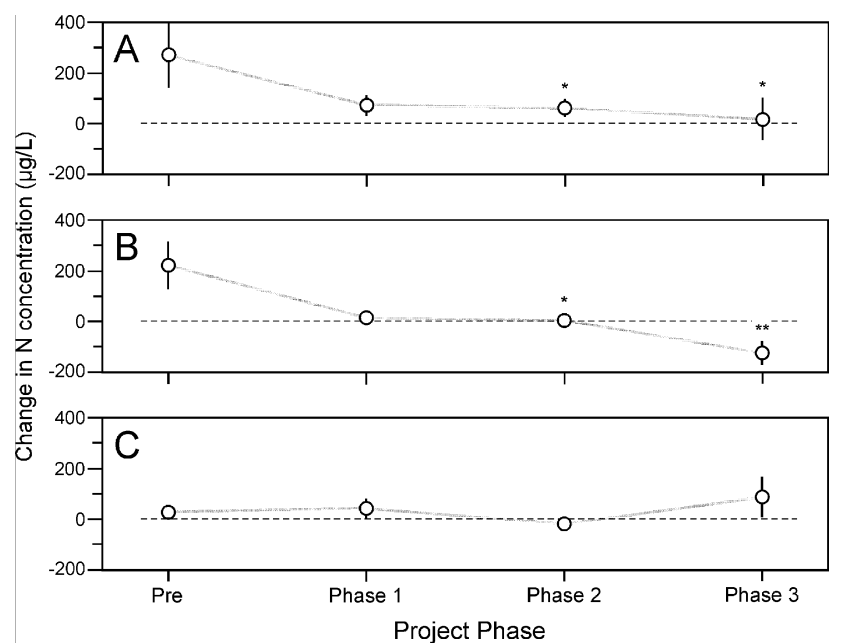

Fig. 11. Mean change in nitrogen constituent concentration (delta) through the SWAMP project site (concentration at WT-5 minus concentration at WT-1) by sampling period. A positive number indicates increasing concentration while a negative number indicates decreasing concentration. (A) Total nitrogen, (B) $\left(\mathrm{NO}_{3}{ }^{-}+\mathrm{NO}_{2}{ }^{-}\right)-\mathrm{N}$ and $(\mathrm{C}) \mathrm{NH}_{4}{ }^{+}-\mathrm{N}$. Asterisks indicate significant differences in average deltas between pre-restoration phase ("Pre") and post restoration Phases I-III ( ${ }^{*} p$-value $<0.05$, ${ }^{* *} p$ value $<0.01$ ).

been influenced by all three-project phases, but not by adjacent non-forested land uses such as the Duke University Golf Club. Thus, we compared the mean daily upstream to downstream changes in water quality (or delta) for each sampling period with positive deltas indicating increased concentration and negative deltas indicating decreased concentration of a given constituent.

Prior to restoration, total nitrogen, $\left(\mathrm{NO}_{3}{ }^{-}+\mathrm{NO}_{2}{ }^{-}\right)-\mathrm{N}$, and ammonium concentrations all increased on average as Sandy Creek flowed through the SWAMP project site due to high inputs from tributaries like BR-5 (Fig. 11). Beginning with restoration Phase I, these deltas all approached zero, so that nitrogen attenuation in Phase I appears to negate tributary nitrogen loads within the SWAMP site. In Phases II and III this trend became statistically significant for total nitrogen and $\left(\mathrm{NO}_{3}{ }^{-}+\mathrm{NO}_{2}{ }^{-}\right)-\mathrm{N}$. In Phase III $\left(\mathrm{NO}_{3}{ }^{-}+\mathrm{NO}_{2}{ }^{-}\right)-\mathrm{N}$ concentrations decreased through the site (negative deltas) indicating biological and physical attenuation of $\left(\mathrm{NO}_{3}{ }^{-}+\mathrm{NO}_{2}{ }^{-}\right)-\mathrm{N}$ exceeded tributary $\left(\mathrm{NO}_{3}{ }^{-}+\mathrm{NO}_{2}{ }^{-}\right)-\mathrm{N}$ additions within the SWAMP site. These reductions in nitrate-nitrogen may have been in part the result of increased denitrification found in the higher plant diversity areas of the restored Sandy Creek floodplain by Sutton-Grier and Kenney (2010). It is notable that ammonium concentrations increased through the SWAMP site, likely due to drought and resulting stagnant conditions on some portions of the site. However, this ammonium increase did not offset significant decreases in mean deltas for total $\mathrm{N}$ and $\left(\mathrm{NO}_{3}{ }^{-}+\mathrm{NO}_{2}{ }^{-}\right)-\mathrm{N}$ during Phase III and it is likely that this phenomenon was occurring throughout the New Hope Creek watershed during the summer of 2007. A similar trend in reduced nitrogen species was found by Mitsch et al. (1998) in a created wetland system developed on the Ohio State University campus.

Similar trends were seen for phosphorus concentration deltas (Fig. 12) where total phosphorus concentrations increased slightly through the SWAMP site prior to restoration. Total phosphorus deltas approached zero (no change in concentration) during Phases I and II. During Phase III, deltas for both TP and SRP become negative indicating decreasing phosphorus concentrations through the SWAMP site, probably due to increased P removal in the Phase III treatment wetlands. Mean deltas in Phase III were significantly lower than those of the pre-restoration period, indicating phosphorus removal in the SWAMP site exceeded tributary additions.

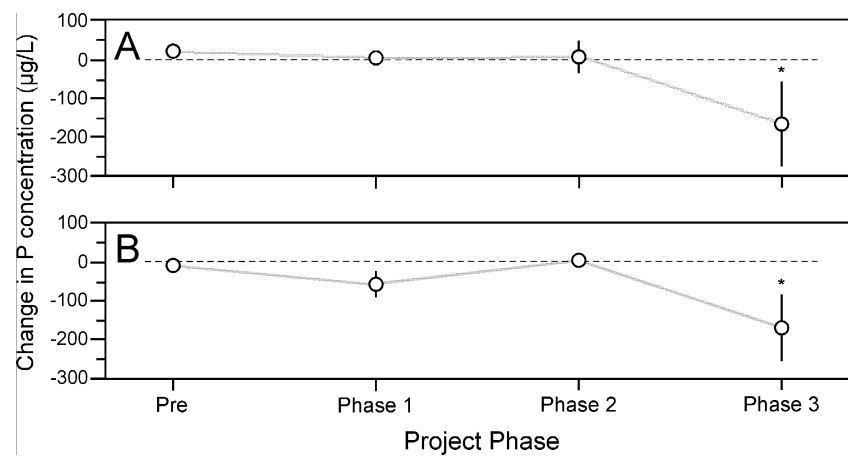

Fig. 12. Mean change in phosphorus constituent concentration (delta) through the SWAMP project site (concentration at WT-5 minus concentration at WT-1) by sampling period. A positive number indicates increasing concentration while a negative number indicates decreasing concentration. (A) Total phosphorus and (B) soluble reactive phosphorus. Asterisks indicate significant differences in average deltas between pre-restoration phase ("Pre") and post restoration Phases I-III ("p-value $<0.05)$.

A similar reduction in phosphorus was also found in created ponds receiving river flow in an urban setting in Ohio (Nairn and Mitsch, 2000). Collectively, our results support the concept of restoring a diversity of wetland types within a watershed to achieve improved water quality services.

\subsection{Estimates of storm nutrient load attenuation}

Prior to restoration activities undertaken as part of SWAMP the Sandy Creek riparian system was no longer capable of improving water quality for stream-borne nutrients, sediments and contaminants (Figs. 8-12). Restoration of three phases has resulted in a significant concentration reduction of major nutrients like $\mathrm{N}$ and $\mathrm{P}$ as well as coliform bacteria and other constituents. However, it is imperative that the ecosystem stream/wetland complex removes a substantial amount of the mass load of nutrients and sediments, especially during a storm event to meet downstream TMDL limits set by the state of North Carolina for the Jordan reservoir. To test the overall effectiveness of SWAMP in terms of $\mathrm{N}$ and $\mathrm{P}$ removal we calculated a mass loading (flow times $\mathrm{N}$ and $\mathrm{P}$ concentrations) over a fairly large 24-h storm event $(2.9 \mathrm{~cm})$ during September $14-15,2007$. The hydrograph for the SWAMP site integrated over the 24-h discharges for the storm event showed a flow of $28,489 \mathrm{~m}^{3} /$ day upstream and $26,422 \mathrm{~m}^{3}$ /day downstream, a difference of only $-7 \%$. This suggests that there was little loss of water due to groundwater loss or evaporation and thus a representative budget could be calculated from these discharge differences. When the $\left(\mathrm{NO}_{3}{ }^{-}+\mathrm{NO}_{2}{ }^{-}\right)-\mathrm{N}$ loads from the mainstream on sandy Creek (WT-1) were combined with the loads coming from Phase III (output from BR-5) this resulted in a $\left(\mathrm{NO}_{3}{ }^{-}+\mathrm{NO}_{2}{ }^{-}\right)-\mathrm{N}$ input of over $20 \mathrm{~kg} /$ day (Fig. 13A). Mass load measurements at DS-1 (downstream output) showed outputs to be approximately $7 \mathrm{~kg} / \mathrm{day}$, a $64 \%$ reduction in load due to the effects of all three-restoration phases. In the same storm event we saw a $28 \%$ reduction in total phosphorus loads (Fig. 13B). Reductions in nutrient concentration, improvement and stabilization of water quality parameters and mass nutrient retention all key ecosystem service of the stream/riparian wetland complex have thus been restored on this portion of the 600 ha urban watershed. However, water quality improvements only took place after SWAMP was fully restored, the result of a reconnection of multiple phases of the riparian floodplain, creation of a treatment wetland and the construction of the storm water/wetland pond downstream of the restored stream and riparian wetlands. 

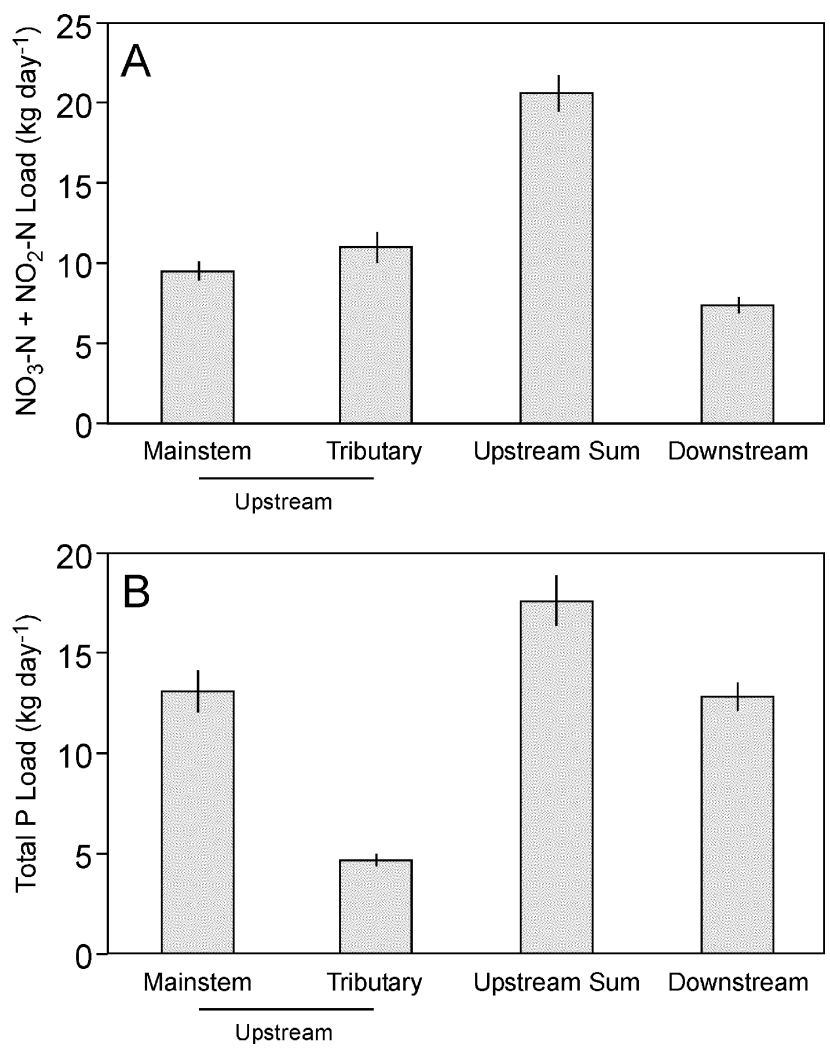

Fig. 13. (A) Storm event $\mathrm{NO}_{3}-\mathrm{NO}_{2}$ loads (discharge $\times$ concentration) upstream and downstream of the SWAMP project area on September 14 and 15, 2007. Bars indicate a 24-h sum. (B) Storm event TP loads (discharge $\times$ concentration) upstream and downstream of the SWAMP project area on September 14-15, 2007. Bars indicate a 24-h sum.

\section{Conclusions}

In response to the recognition that the Upper Sandy Creek stream and floodplain ecosystem had become dysfunctional due to the effects of altered storm water delivery following watershed development, a three-phase stream and floodplain restoration was planned to increase the stream wetland connection and improve nutrient removal and ecosystem processing services. We used an integrated stream/riparian restoration approach to hydrologically reconnect the stream with the adjacent floodplain and allow natural riparian wetland biogeochemistry transformations to improve stream water quality.

Well and piezometer data indicated that four years after restoration, low and high bench sites in the riparian floodplain had functioning wetland hydrology. The low bench areas closest to the stream were often flooded, especially after storms. In fact all contoured floodplain benches met wetland criteria across a range of annual precipitation totals from wet to drought conditions, suggesting a strong connection with the restored stream.

We found impaired water quality in the Upper Sandy Creek Watershed under both ambient and storm flow conditions. The level of impairment differed between various response parameters and varied over time. Fecal coliforms throughout most of the watershed were in excess of published State of NC water quality standards in the period prior to August, 2005 and declined steadily through 2007, likely in part due to the onset of extreme drought conditions in late 2006 and lasting through 2007. Though there had been a watershed-wide trend of lower fecal concentrations over time, the stations downstream of the SWAMP were the only sites with a statistically significant decrease of fecal coliform counts for consecutive sampling periods.

Throughout the Sandy Creek watershed parameters such as $\mathrm{N}$ and $\mathrm{P}$ were in excess of EPA recommendations for the ambient water quality of Piedmont streams prior to any restorations. A replicated Before-After-Control-Impact (BACI) analysis of changes in ambient nitrogen and phosphorus through the SWAMP site using paired sites near the upstream and downstream boundaries showed nutrients often increased through the project site prior to restoration. After restoration, nutrients mostly decreased, indicating rates of nutrient attenuation within the SWAMP site equaled or exceeded nutrient additions from tributary loads. After Phase III, mean nutrients were significantly lower than they had been pre-restoration for all $\mathrm{N}$ and $\mathrm{P}$ constituents except $\mathrm{NH}_{4}{ }^{+}-\mathrm{N}$. Storm event hydrologic and nutrient budgets based on mass loading indicate substantial attenuation of nutrients within SWAMP project. Most notably, $\left(\mathrm{NO}_{2}{ }^{-}+\mathrm{NO}_{3}{ }^{-}\right)-\mathrm{N}$ loads were reduced by $64 \%$ and $\mathrm{TP}$ loads were reduced by $28 \%$. Sediment retention in the restored wetlands and stormwater reservoir totaled nearly 500 metric tonnes per year.

The multi-phased restoration of Sandy Creek using natural stream design principles and re-contoured adjacent wetlands resulted in a restoration of the floodplain riparian hydrology, which reduced downstream water pulses and stream erosion. Most importantly we found sediment retention and improved water quality for nutrients and coliform bacteria leaving the watershed of the City of Durham and Durham County prior to release into streams entering Jordan reservoir. The improvement of these ecosystems services within the watershed will reduce downstream pollution and greatly increase the wetland habitat.

\section{Acknowledgments}

This water quality research was made possible by $319(\mathrm{~h})$ Nonpoint Source Program grant number EW05040 from the North Carolina Department of Environment and Natural Sciences/Division of Water Quality and support by the Duke University Wetland Center (DUWC) Endowment Fund and Wetlands Case Studies Fund. Major funding was provided for construction of the restoration sites by a North Carolina Clean Water Management Trust Fund grant and a NC Division of Water Resources grant. Invasive species removal and replanting for the sites was paid for by a USDA grant. We would also like to acknowledge our cooperating agencies and organizations on this project: North Carolina Ecosystem Enhancement Program, Clean Water Management Trust Fund, New Hope Creek Corridor Committee, District, City of Durham, and Duke Forest Director Judd Edeburn and his staff for invaluable assistance on the construction of the site. The Durham Soil and Water Conservation staff and director Eddie Culberson have been a major supporter and partner in this effort. The authors would like to thank in particular the following staff and students of the Duke University Wetland Center for their assistance in data collection and sample analysis: Erin Brosnan, Julie DeMeester, Ryan Elting, Doug Gorecki, Amy Hammontree, Lauren Kinsman, Mike Osland, Ariana SuttonGrier, Joshua Unger and Joe Williams. Wes Willis and Paul Heine provided key laboratory chemical analysis and data base management and Randy Neighbarger aided greatly with editing and finding reference materials A key to this project was project approval and donation of the lands by the Duke University Administration and in particular Tallman Trask. Finally, this project would not have been possible without the aid of more than 150 Duke graduate students who for nearly 10 years in the wetland restoration class crawled through the jungles of weeds, poison ivy and deeply entrenched stream beds to help design various phases of SWAMP. 


\section{Appendix A.}

Significant changes in ambient monitoring variables with interactions between periods with sample station. Test where performed with multiple comparison of means, and a significance level of $p=0.05$ with Dunnett procedure for multiple comparison to a control. "+" indicates a significant increase in mean value between periods, “-” indicates a significant decrease in mean value between periods. Cntl - (control) upstream for most stations in a given tributary (e.g. WT-1, WT-3, BR-1, NHCU) during "Prior" (Pr) or phase 1 (P1) P2 or P3 study phase.

\begin{tabular}{|c|c|c|c|c|c|c|c|c|c|c|c|c|c|c|c|c|c|c|}
\hline & & $\begin{array}{l}\text { Temp } \\
\left({ }^{\circ} \mathrm{C}\right)\end{array}$ & $\mathrm{pH}$ & Fecal & D.O. & $\begin{array}{l}\text { Spec. } \\
\text { cond. }\end{array}$ & $\begin{array}{l}\text { Total } \\
\text { dis. } \\
\text { solids }\end{array}$ & $\begin{array}{l}\text { Total } \\
\text { solids }\end{array}$ & Turbidity & $\mathrm{Ca}$ & $\mathrm{Mg}$ & $\mathrm{K}$ & $\mathrm{Na}$ & $\mathrm{NO}_{3}{ }^{-}-\mathrm{NO}_{2}{ }^{-}$ & $\mathrm{NH}_{4}$ & $\begin{array}{l}\text { Total } \\
\mathrm{N}\end{array}$ & $\begin{array}{l}\text { Total } \\
\mathrm{P}\end{array}$ & $\begin{array}{l}\text { Sol. } \\
\text { reactive } \\
\text { P }\end{array}$ \\
\hline WT-1 & P1-Cntl & & & & & & & & & & & & & & & & & \\
\hline WT-1 & P2-Cntl & & & & & & & & & & & & & & & & & \\
\hline WT-1 & P3-Cntl & & & - & - & & & & & & & & & & & + & & \\
\hline WT-6 & Pr-Cntl & & & & & & & & & & & & & & & & & \\
\hline WT-6 & P1-Cntl & & & & & & & & & & & & & & & & & \\
\hline WT-6 & P2-Cntl & & & & & & & & & & & & & & & & & \\
\hline WT-6 & P3-Cntl & & & - & & & & & & & & & & & & + & & \\
\hline WT-2 & Pr-Cntl & & & & & & & & & & & & & & & & & \\
\hline WT-2 & P1-Cntl & & & & & & & & & & & & & & & & & \\
\hline WT-2 & P2-Cntl & & & & & & & & & & & & & & & & & \\
\hline WT-2 & P3-Cntl & & & - & - & & & & & & & + & & & & + & & \\
\hline WT-4 & Pr-Cntl & & & & & & & & & & & & & & & & & \\
\hline WT-4 & P1-Cntl & & & & & & & & & & & & & & & & & \\
\hline WT-4 & P2-Cntl & & & & & & & & & & & & & & & & & \\
\hline WT-4 & P3-Cntl & & & - & - & & & & & & & & & & & + & & \\
\hline WT-5 & Pr-Cntl & & & & & & & & & & & & & & & & & \\
\hline WT-5 & P1-Cntl & & & & & & & & + & & & & & & & & & \\
\hline WT-5 & P2-Cntl & & - & - & & & & & & & & & & & & & & \\
\hline WT-5 & P3-Cntl & & & - & - & & & & & & & & & - & & + & & \\
\hline DS-1 & Pr-Cntl & & & & & & & & & & & & & & & & & \\
\hline DS-1 & P1-Cntl & & & & & & & & & & & & & & & & & \\
\hline DS-1 & P2-Cntl & & - & & & & & & & & & & & & & & & \\
\hline DS-1 & P3-Cntl & & & - & - & & & & & & & & & & & + & & \\
\hline WT-3 & P1-Cntl & & - & - & & & & & & & & & & & & & & \\
\hline WT-3 & P2-Cntl & & - & & & & & & & & + & - & & & & & & \\
\hline WT-3 & P3-Cntl & & & & - & & & & & - & & & - & & & + & + & \\
\hline BR-5 & P1-Cntl & & & & & & & & & & & - & & - & & & & \\
\hline BR-5 & P2-Cntl & & - & - & & - & & & & - & - & - & & - & & & & \\
\hline BR-5 & P3-Cntl & & & & & - & & & & - & - & - & & - & & & & + \\
\hline $\mathrm{NCHU}$ & P1-Cntl & & & & & & & & & & & & & & & & & \\
\hline NHCU & P2-Cntl & & & & & & & & & & & & & & & & & \\
\hline NHCU & P3-Cntl & & & & - & & & & & - & & + & + & & & + & & \\
\hline NHCD & P1-Cntl & & & & & & & & & & & & & & & & & \\
\hline NHCD & P2-Cntl & & & & & & & & & & & & & & & & & \\
\hline NHCD & P3-Cntl & & & & - & & & & & & & + & + & & & + & + & + \\
\hline
\end{tabular}

\section{References}

Bedford, B., 1999. Cumulative effects on wetland landscapes: links to wetland restoration in the United States and southern Canada. Wetlands 19(4), 775-788.

Bernhardt, E.S., Palmer, M.A., Allan, J.D., Alexander, G., Barnas, K., Brooks, S., Carr, J., Clayton, S., Dahm, C., Follstad-Shah, J., Galat, D., Gloss, S., Goodwin, P., Hart, D., Hassett, B., Jenkinson, R., Katz, S., Kondolf, G.M., Lake, P.S., Lave, R., Meyer, J.L., O'Donnell, T.K., Pagano, L., Powell, B., Sudduth, E., 2005. Synthesizing U.S. river restoration efforts. Science 308 (5722), 636-637.

Bernhardt, E.S., Palmer, M.A., 2007. Restoring streams in an urbanizing world. Freshwater Biol. 52 (4), 738-751.

Brinson, M.M., 1977. Decomposition and nutrient exchange of litter in an alluvial swamp forest. Ecology 58 (3), 601-609.

Buol, S.W., 2003. Formation of soils in North Carolina. In: Papers Commemorating a Century of Soil Science. Soil Science Society of North Carolina, Raleigh, pp. 31-56. http://agronomy.agr.state.nc.us/sssnc/century.pdf.

Cahoon, D.R., Turner, R.E., 1989. Accretion and canal impacts in a rapidly subsiding wetland. II. Feldspar marker horizon technique. Estuaries 12 (4), 260-268.

Doll, B.A., Wise-Frederick, D.E., Buckner, C.M., Wilkerson, S.D., Harman, W.A., Smith, R.E., Spooner, J., 2002. Hydraulic geometry relationships for urban streams throughout the Piedmont of North Carolina. J. Am. Water Res. 38 (3), 641-651.

Doll, B.A., Grabow, G.L., Hall, K.R., Halley, J., Harman, W.A., Jennings, G.D. Wise, D.E., 2003. Stream Restoration: A Natural Channel Design Handbook. NC Stream Restoration Institute, NC State University, Raleigh, NC. http://www.bae.ncsu.edu/programs/extension/wqg/sri/stream_rest_guidebook/ sr_guidebook.pdf.

Elting, R.J., 2003. A Pre-restoration Hydrologic Assessment and Nutrient Budget for Sandy 30 Creek, Durham, NC. Master's Project, Duke University, Nicholas School of the Environment and Earth Sciences, Durham, NC.

Flanagan, N.E., Richardson, C.J., Ho, M., Pahl, J.W., Roberts, B.T., Medley, L., 2008. Quantification of Water Quality Improvement in Sandy Creek, A Tributary Watershed of Jordan Lake in the Cape Fear River Basin, After Stream and Ripar- ian Restoration and Wetland Treatment Cell Creation: Final Report of Scientific Findings to the Nonpoint Source Management Program, Division of Water Quality, NC Department of Environment and Natural Resources. Duke University Wetland Center, Durham, NC, $134 \mathrm{pp}$.

Forest History Society, 2000. If trees could talk. http://www.foresthistory. org/education/Curriculum (accessed 29.04.10).

Green, R.H., 1979. Sampling Design and Statistical Methods for Environmental Biologists. Wiley Interscience, Chichester, UK.

Haycock, N.E., Pinay, G., 1993. Groundwater nitrate dynamics in grass and poplar vegetated riparian buffer strips during the winter. J. Environ. Qual. 22 (2), 273-278

Johnston, C.A., Bridgham, S.D., Schubauer-Berigan, J.P., 2001. Nutrient dynamics in relation to geomorphology of riverine wetlands. Soil Sci. Soc. Am. J. 65 (2), 557-577.

Kirby, R.M., 1976. Soil Survey of Durham County North Carolina. USDA, Soil Conservation Services, Washington, DC.

Lake, P.S., Bond, N., Reich, P., 2007. Linking ecological theory with stream restoration. Freshwater Biol. 52 (4), 597-615.

Lawson, J., 1714. New Voyage to North Carolina. W. Taylor and J. Baker, London.

Luczkovich, J.J., Knowles, D., 2001. Environments and ecosystems of North Carolina. http://core.ecu.edu/BIOL/luczkovichj/NCecol/NCnathis.htm (accessed 07.05.10).

Mitsch, W.J., Wu, X., Nairn, R.W., Weihe, P.E., Wang, N., Deal, R., Boucher, C.E., 1998 Creating and restoring wetlands: a whole-ecosystem experiment in self-design. BioScience 48, 1019-1030.

Mitsch, W.J., Horne, A.J., Nairn, R.W., 2000. Nitrogen and phosphorus retention in wetlands-ecological approaches to solving excess nutrient problems. Ecol. Eng. $14(1-2), 1-7$.

Mitsch, W.J., Lefeuvre, J.C., Bouchard, V., 2002. Ecological engineering applied to river and wetland restoration. Ecol. Eng. 18 (5), 529-541.

Mitsch, W.J., Gosselink, J.G., 2007. Wetlands, 4th ed. Wiley, Hoboken, NJ 
Nairn, R.W., Mitsch, W.J., 2000. Phosphorus removal in created wetland ponds receiving river overflow. Ecol. Eng. 14 (1-2), 107-126.

NCDENR/DWQ 2003. North Carolina Water Quality Assessment and Impaired Waters List. 2002 Integrated 305(b) and 303(d) Report. Document Control No. 021RMT04Ff, 184 pp.

NCDENR/DWQ, 2004. "Redbook" Surface Waters and Wetlands Standards (NC Administrative Code 15a NCAC 02b.0100 \&.0200), Amended Effective: August 1 , 2004. 133 pp. http://h2o.enr.state.nc.us/admin/rules/documents/rb080104.pdf.

NCDENR/DWQ, 2007. B. Everett Jordan Reservoir, North Carolina Phase Total Maximum Daily Load, 91 pp. http://h2o.enr.state.nc.us/tmdl/documents/ JordanLakeTMDLFinal.pdf.

Paulsen, S., Stoddard, J., Holdsworth, S., Mayio, A., Tarquinio, E., 2006. Wadeable Streams Assessment: A Collaborative Survey of the Nation's Streams. EPA/841/B-06/002, 117 pp.

Pinay, G., Clement, J.C., Naiman, R.J., 2002. Basic principles and ecological consequences of changing water regimes on nitrogen cycling in fluvial systems. Environ. Manage. 30 (3), 481-491.

Richardson, C.J., 1994. Ecological functions and human values in wetlands: a framework for assessing forestry impacts. Wetlands 14 (1), 1-9.

Richardson, C.J., 1999. The role of wetlands in storage, release and cycling of phosphorus on the landscape: a 25-year retrospective. In: Reddy, K.R. (Ed.), Phosphorus Biogeochemistry in Sub-Tropical Ecosystems. CRC Press/Lewis Publishers, pp. 47-68.

Rosgen, D.L., 1994. A classification of natural rivers. Catena 22, 169-199.

Rosgen, D.L., 2007. Geomorphic channel design. In: Bernard, J., Fripp, F., Robinson, K.R. (Eds.), Stream Restoration Design National Engineering Handbook. 210-VINEH. USDA/NRCS, Washington, DC, pp. 11/1-11/76.

Schafale, M.P., Weakley, A.S., 1990. Classification of the Natural Communities of North Carolina: Third Approximation. MSC 1615 North Carolina Natural Heritage Program, NCDENR, Raleigh, NC. http://www.ncnhp.org/Images/ Other\%20Publications/class.pdf.

Shields Jr., F.D., Lizotte Jr., R.E., Knight, S.S., Cooper, C.M., Wilcox, D., 2010. The stream channel incision syndrome and water quality. Ecol. Eng. 36 (1), 78-90.

Stewart-Oaten, A., Murdoch, W.W., Parker, K.R., 1986. Environmental impact assessment: "pseudoreplication" in time? Ecology 67 (4), 653-694.

Sutton-Grier, A.E., Kenney, M.A., Richardson, C.J., 2010. Examining the relationship between ecosystem structure and function using structural equation modeling: a case study examining denitrification potential in restored wetland soils. Ecol. Model. 221, 761-768.

Trimble, S.W., 1974. Man-Induced Soil Erosion on the Southern Piedmont: 1700-1970. Soil and Water Conservation Society of America, Akeny, IA

Turley, E., 2001. The Effects of Wetland Restoration on Water Quality: A Baseline Assessment of Water Quality Indices in the Sandy Creek Project Area, Durham, North Carolina. Master's Project, Duke University, Nicholas School of the Environment, Durham, NC.

Unghire, J.M., Sutton-Grier, A.E., Flanagan, N.E., Richardson, C.J., 2010. Spatial impacts of stream and wetland restoration on riparian soil properties in the North Carolina Piedmont. Restor. Ecol., 00726, doi:10.1111/j.1526-100X.2010.

USACE, 1987. Corps of Engineers Wetlands Delineation Manual. Technical Report Y-87-1, NTIS No. AD A176 912, January 1987, 143 pp.

USDA/NRCS, 2009. Hydric Soils of the United States. Soil Conservation Service in Cooperation with the National Technical Committee for Hydric Soils, Washington, DC. http://soils.usda.gov/use/hydric/lists/state.html (accessed 29.04.10).

USEPA, December 1989. Risk Assessment Guidance for Superfund. Volume I: Human Health Evaluation Manual (Part A) Interim Final. EPA/540/1-89/002, 1989, 289 pp.

USEPA, July 2000a. Guidance for Data Quality Assessment: Practical Methods for Data Analysis. USEPA Office of Environmental Information. EPA/600/R-96/084, 2000, 219 pp.

USEPA, December 2000b. Ambient Water Quality Criteria Recommendations Information Supporting the Development of State and Tribal Nutrient Criteria Rivers and Streams in Nutrient Ecoregion IX. EPA/822/B-00/019, 108 pp.

USEPA, August 2002. National Water Quality Inventory 2000 Report. EPA-841-R-02001, $207 \mathrm{pp}$.

Walter, R.C., Merritts, D.J., 2008. Natural streams and the legacy of water-powered mills. Science 319 (5861), 299-304.

Watts, S.C., 2000. The Effects of Reduced Flooding Frequency on Species Composition in a Bottomland Hardwood Stand in the Piedmont of North Carolina. Master's Project Duke University. Nicholas School of the Environment, Durham, NC.

Zedler, J.B., 2000. Progress in wetland restoration ecology. Trends Ecol. Evol. 15 (10), 402-407.

Zedler, J.B., 2003. Wetlands at your service: reducing impacts of agriculture at the watershed scale. Front. Ecol. Environ. 1 (2), 65-72. 